\title{
قاعدة سلد الذرائع وأثرها في باب النكاح عند المالكية
}

\section{أعده / د. حسن الطاهر الشيخ الطيب}

قسم أصول الفقه كلية العلوم والدراسات الإنسانية

\section{جامعة المجمعة ـ السعودية}

ملخص البـحث:

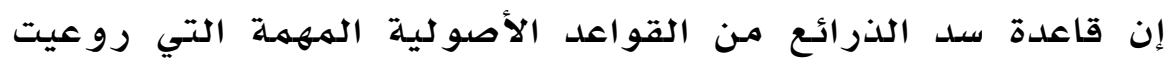

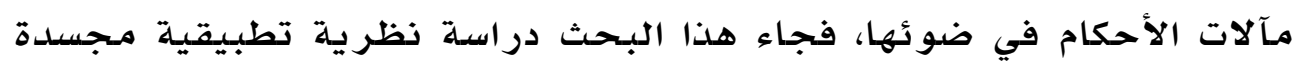

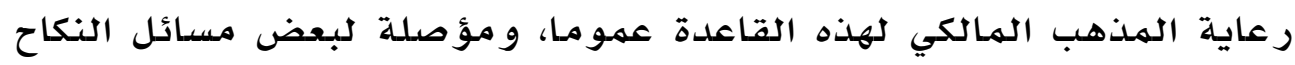

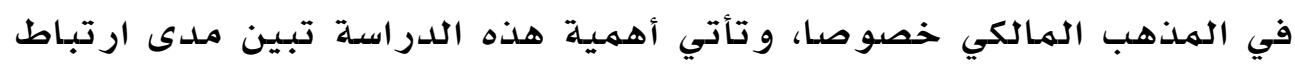
هذه القاعدة بهقصد حفظ النسل، و إبر ازه دور ها في استنباط الأحكام.

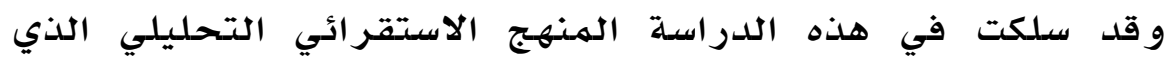

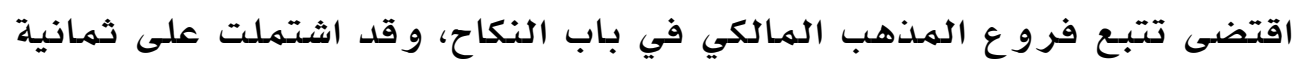

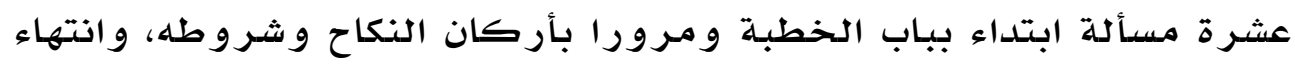
بالهعاشرة و أحكامها. وانتهيت في هذا البحث إحكا. إلى نتائج أهمها:

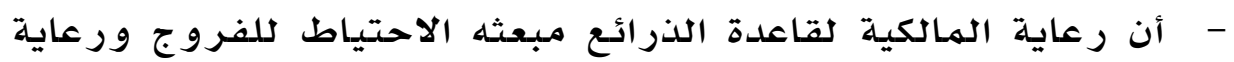
مقصد حفظ النسل. - مـآلات الأفعال والأقوال لها حظ من النظر في التشريع الإسدامي.

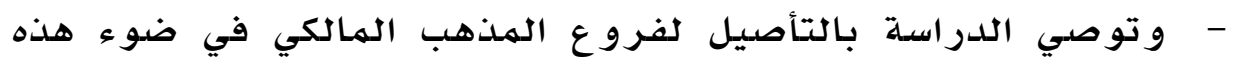
القاعدة و في غيرها من الأصول الهعتبرة الأخرى.

الكلمات المفتاحية: سد الذرائع _ فتح الذرائع _ حفظ النسل 


\section{Abstract}

This study investigates one of the most important principles upon which the consequences of conventions are based. Therefore, it is considered as applied theoretical study reflecting the Maliki doctrine in general and setting the basic conditions of marriage in the Maliki's doctrine in particular. The significance of this study arises to clarify to how extend the connection of this principle with the aim of protecting the offspring and reflecting its role in extrapolating the provisions. This study is based on the inductive and analytical method which entails tracing the branches of the Maliki's doctrine regarding the marriage chapter which consists of eighteen points of relevance, starting from betrothal through marriage conditions and ending with the terms of sexual intercourse. This study arrives at the following results: The adoption of the Maliki's pretext principle stems out of the following facts:

1. Protection of human genitals.

r. Continuation of the offspring .

$r$. The consequences of the actions and verbal talks are considered in the Islamic jurisdiction.

This study recommends the rooting of the branches of the Maliki school of thought on this rule and other significant origins

Keywords:(Averting the pretexts - opening the pretexts - the purpose of offspring). 
الحمد الله رب العالهين الذي نهى عن سب آلهة الكفار؛ دئلا يكون

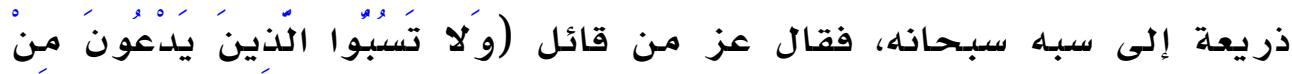

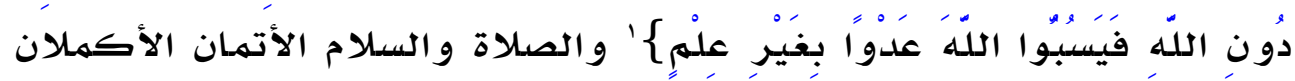
على الهبعوث رحمهة للعالمين سيد ولد آدم و على آله ووصحبـه ومن تبعهم بإحسان إلى يوم الدين

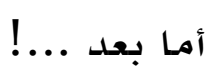

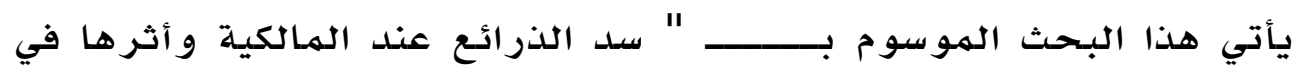
النكاح" لنقف من خلاله على دقة فقهاء الهالكية في استنباط الأحكام الفقهية المبنيـة على هذه القاعدة في باب النكاح، و لنقف على مدى رعايتهم لمقاصد الشرع في حفظ النسب و الاحتياط للأبضاع.

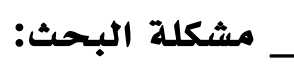

اـ مـا دور قاعدة سد الذرائع في عملية استتبـاط الأحكام؟

Y- مـا مدى ارتباط قاعدة سد الذرائع بمقصد حفظ النسل؟

$$
\text { r- هل كل ذر يعة تسـد؟ }
$$

عـ ما أوجه اعتبار الهالكية للذرائع عند بناء بعض أحكام النكاح عليها؟ _ أهمية الموضوغ:

$$
\text { تظهر أهميـة الهوضوع في الآتي: }
$$

ا- إبراز دور قاعدة سـ الذرائع في استتبـاط الأحكام. 


\section{r- بيان مدى ارتباط القاعدة بهقصد حفظ النسل. \\ rـ- بيان أوجـه أخذ فقهاء الهالكية بالقاعدة في باب النكاح.

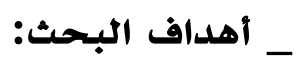

ا ـ التعر ف على قاعدة الذرائع وحجيتها و مدى مـلاءمتها لهقاصد الشرع. צ- ابر از الأثر الفقهي لقاعدة الذرائع في باب النكاح عند الهالكية.

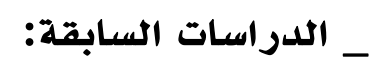

تناول الأصوليون قديها وحديثا قاعدة سلد الذرائع بالدراسـة والتفريع عليها غير أني له أقف على من فرع عليها في باب النكاح عند الهالكية ، وإن كانت هناتك دراسات عنت بهذه القاعدة وتفريعاتها على المدهب الهالكي إلا أن التفريع عليها كان على جل الأبواب الفقهية لا سيها باب الهعامـلات الهـالية، ومن أبرز مـا اطلعت عليه من الدراسـات الهعاصرةـ كتاب سلد الذرائع في الفقه الهـالكي لهؤلفه د. مـحمد بن أحمد سيد سمة أحمد زروق ، وقد تناول الهؤلف في كتابه القاعدة بصدورة عامـة من حيث الهفهوم و الحجية و أحكامها و أقسامها و الأسس التي تقوم عليها و الضوابط التي تتحكم في منهج الهـالكية في سد الذرائع ، واستشهد لها بفروع فقهية من أبواب شتى ، وربها لهم يتجاوز استشهاده في باب النكاح ثلاثة أو أربعة مسائل.

و مـها امـتازت بـه هذه الدراسـة تأصيلها لجل الهسـائل في باب النكاح، مـع بيان وجه سلد الذريعة في كل مسألة.

_ أسباب اختيار الموضوع:

اـ - ابر از الأثر الفقهي لقاعدة الذرائع وبيان أهميتها في استتبـاط الأحكام r- التأصيل الفقهي لهسائل النكاح عند المالكية وبيان وجه رعايتهم لقاعدة 


\section{_ منهج البحث:}

ــ منهج البحث: سلك الباحث المنهج الاستقرائي التحليلي، والتزم فيه بالآتي:

ا- التفريع على القاعدة من باب النكاح، وتحرير الهسألة محل البحث

$$
\text { تحرير ا دقيقًا. }
$$

$$
\text { r- عزو الآيات إلى سور ها. }
$$

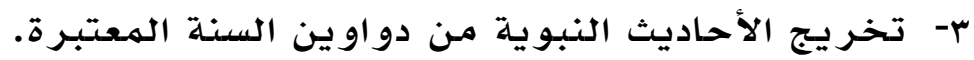

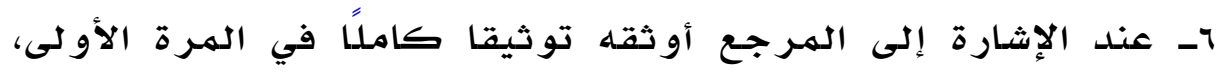

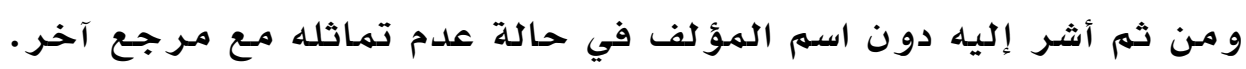

خطة البحث:

الهبحث الأول: مفهوم الذرائع والفرق بين الذريعة و الهقدمـة والذريعة و الحيلة الهبح الهطلب الأول: مفهوم الذيلة الذريعة في اللغة

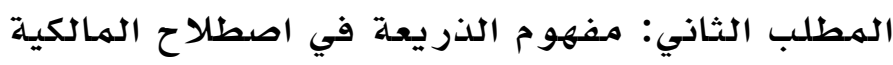

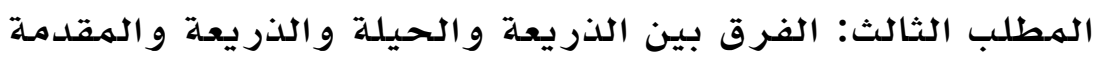

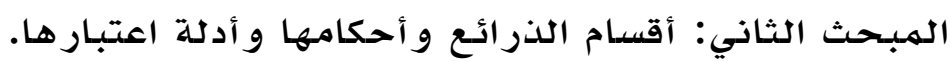

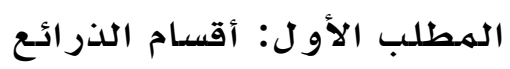

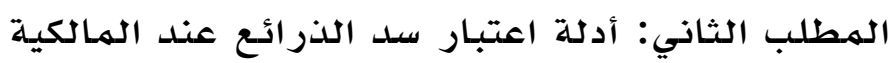
المبحث الثالث: تطبيقات سد الذرائع في باب النكاح عند المالكية.

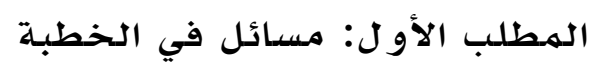

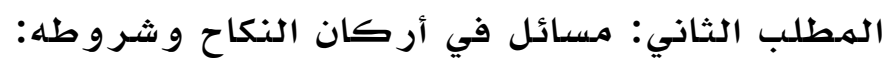

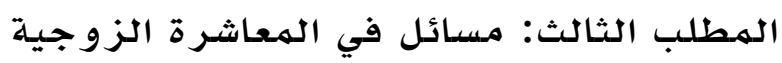

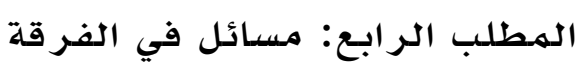


المبحثُ الأول: مفهوم الذرائع والفرق بين الذريعة والمقدمة والذريعة والحيلة

\section{الإطلب الأول: مفهوم الذريعة في اللغة:}

الذريعة في اللغة: أصلها ذرع، وتأتي في اللغة بهعان عدة منها: الذراع العضو الهـهتد مهما بين طرف الهـرفق إلى طرف الإصبـع الوسطى،...والذراع من يد البعير فوق الوظيف، وكذلك من الخيل

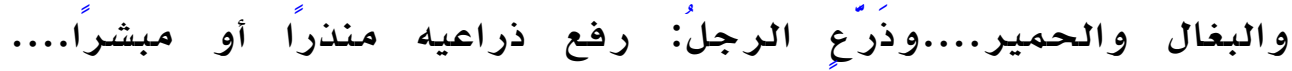
و التذّرّيع في الهشي: تحريك الذّراعين'، و من معانيها السبب، يُقال: فلان

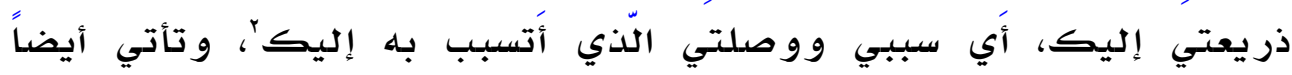
بمعنى الوسيلة: قال في مختتار الصحاح و الذريعة الوسيلة وقد تذرّع فلان بذريعة، أَيْ توسل بوسيلة بـلّ والناقة التي يستتر بها رامي الصسيد ذيظفر بصيده تسهى الذرع، قال أبو بكر الأنباري: الذريعة معناها في كلام

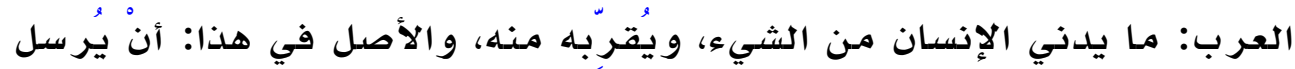
البعيرُ مـع الوحش ير عى معها، حتى يأنس بالوحش، و يأنس بـه الوحش. فإذا أراد الرجل أن يصيدها استتر بـالبعير، حتى إذا حاذى الوحش وداناها، رماها

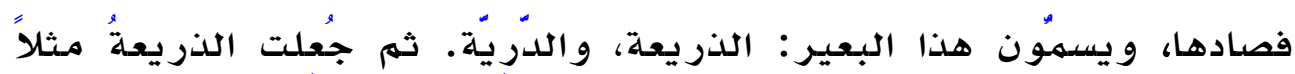

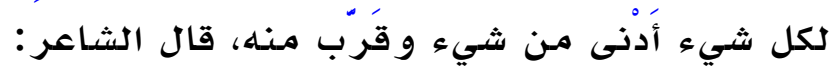

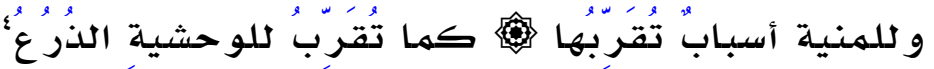

ـ ابن منظور، لسـان العرب، الطبعة: الثالثة - عاعاهـ، الناشر: دار صادر - بيروت، $.97 / \wedge$ ' ـ مر تضى، الزبّيدي، تاج العروس مـن جواهر القاموس، النـاشر: دار الهداية، مجهموعة

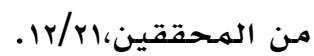

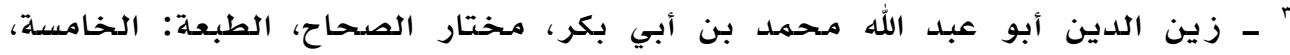

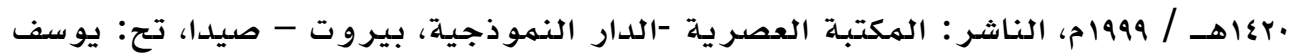

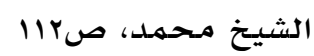
" ـ محمد بن القاسهم بن محمد بن بشار، أبو بكر الأنباري، الزاهر في معاني كلمهات

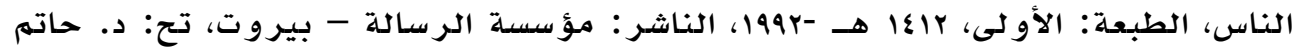


فهـن خلال هذه التعريفات اللغويـة يهكنـنا أن نوجز معنى الذريعة في كل مـا يتخذ وسيلة إلى غيره، و بقيد الاتخاذ يخر ج ما يؤدي عفويًا إلى أمـر مـا، فلا يكون ذريعة إليـه في عرف اللغـة'

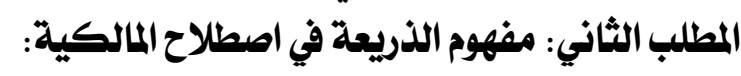

عرف فقهاء المالكية الذرائع بتعر يفات نذكر منها:

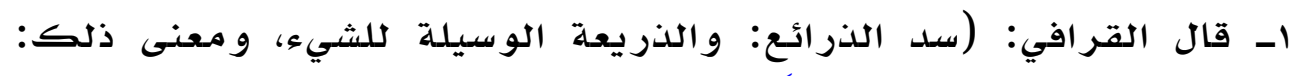

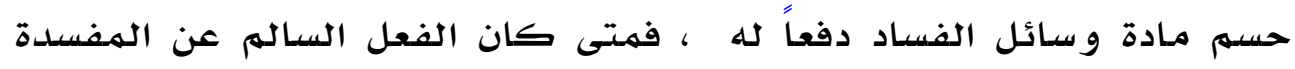

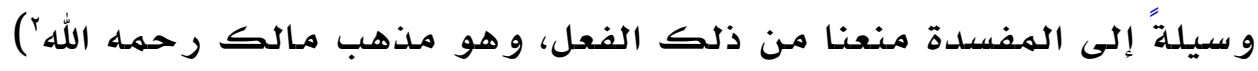
r- قال القاضي عبد الوهاب: (الذرائع هي الأمر الذي ظاهره الجواز إذا مـأ

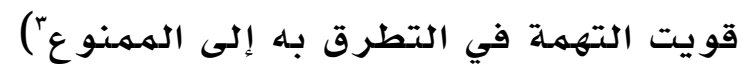
بـ قال قاسهم بن خلف: (الذرائع الأصل فيها استباحة الهنهي عنه بـالحيلة ؛) عـ قال أبو الوليد محمد بن رشد ة)هي الأشياء التي ظاهرها الإباحة

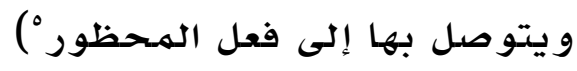

هـ قال الشاطبي: الذرائع (حقيقتها التوسل بهـا هو مصدلحة إلى مفسدة) و مـن خلال هذه التعريفات يهكننا القول بأن الذريعة عند الهالكيـة هي: الوسائط والحيل الهباحة التي تؤدي إلى المهنوع قصدا إليه.

' ـ محمد هاشهم البرهاني، سد الذرائع في الشريعة الإسلامية، الطبعة الأولى بـعاهـ

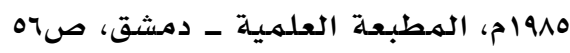

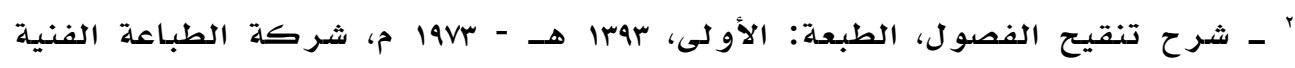

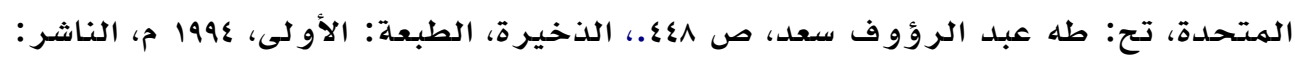

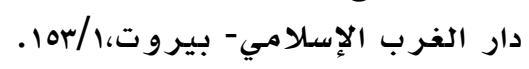

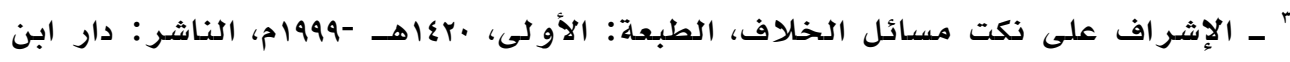

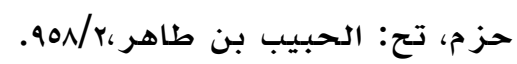

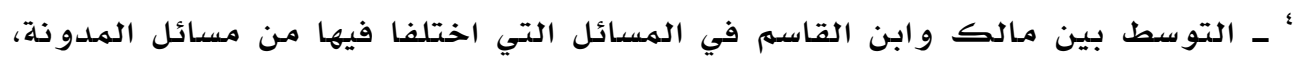

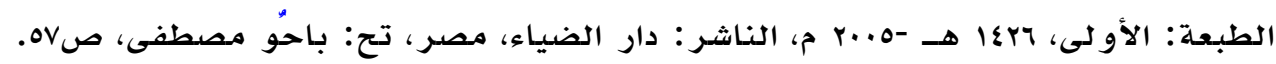

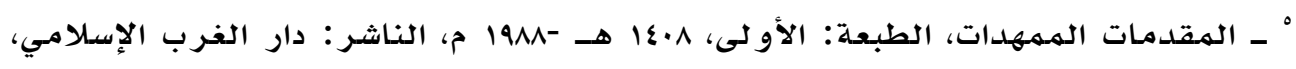

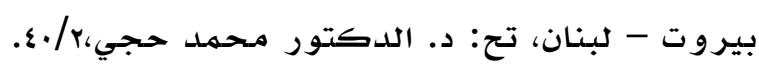

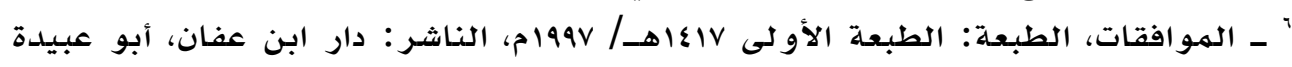

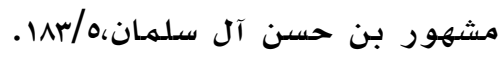


المطلب الثالث: الفرق بين الذريعة والحيلة والذريعة والمقدمة:

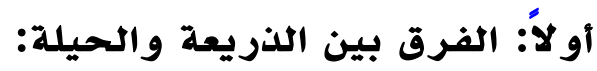

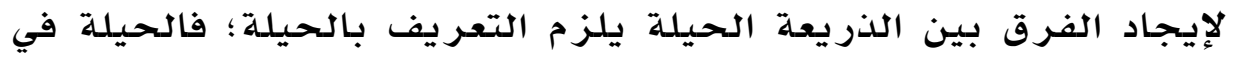

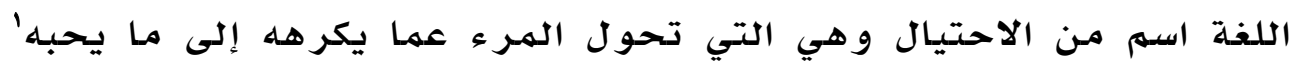

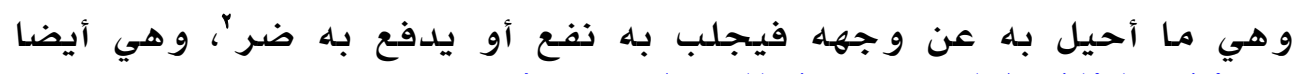

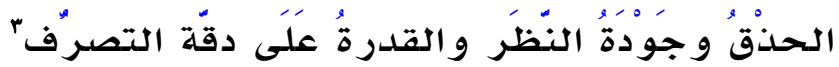

وهي أيضا: ما يتوصل به إلى الى حالة ما خفية والى وأكثر استعهماله فيما في

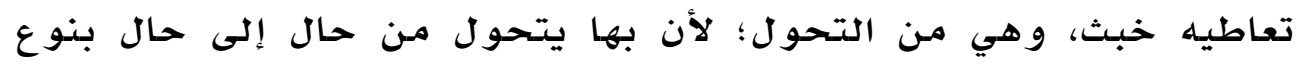

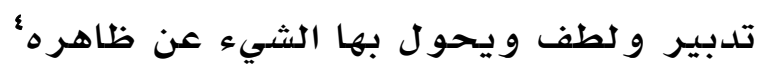

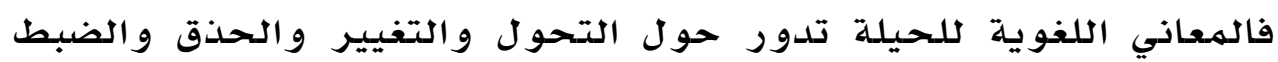

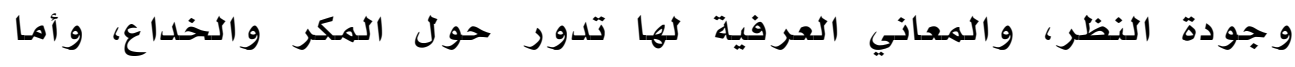

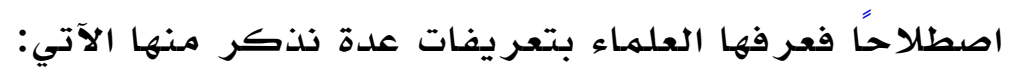

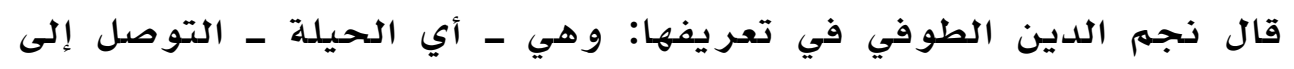

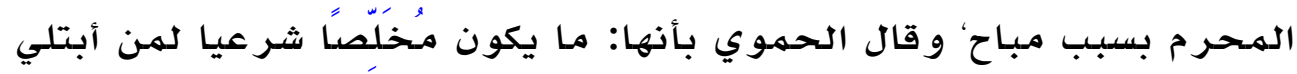

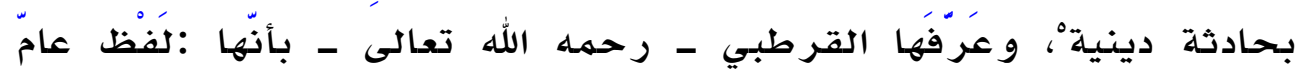

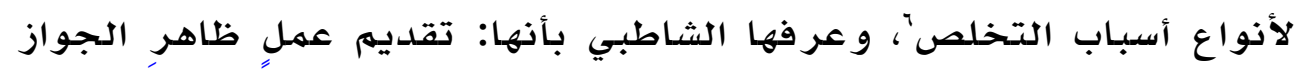

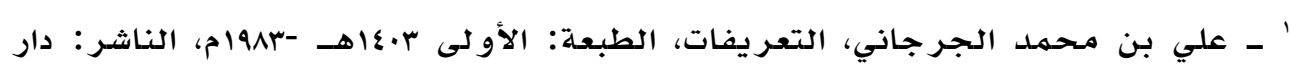

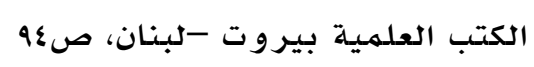

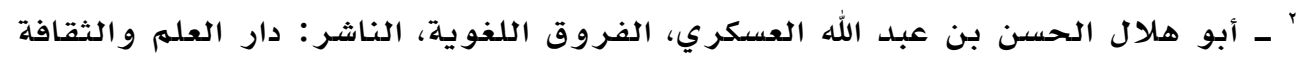

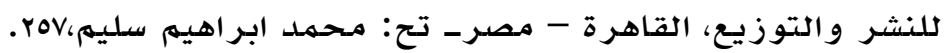

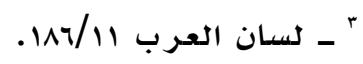

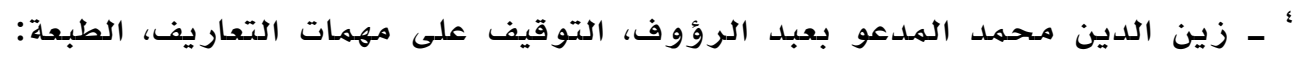

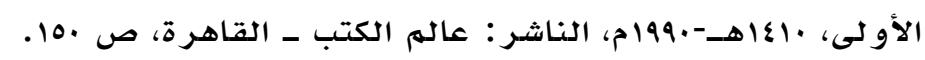

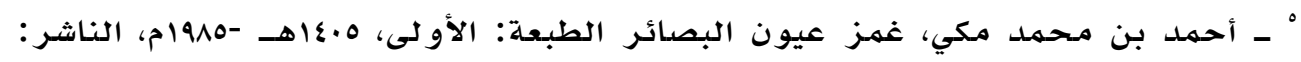

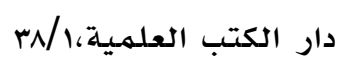

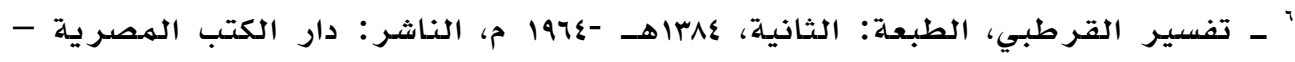

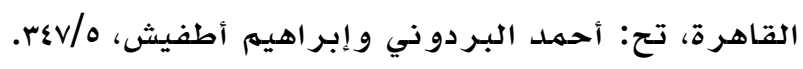




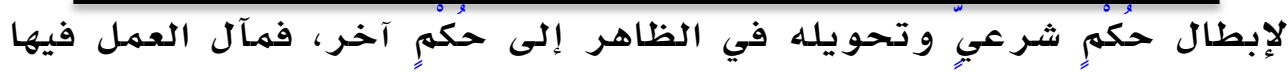
خَرَّمُ قو اعد الشر يعة.

و مـن خلال هذه التعر يفات نخلص إلى أن الحيلة في هذا البـاب المقصود بها الحيلة الهذمومة الهـناقضة لسد الذرائح، لأنها هي الهـرادة عند الإطلاق في عرف الفقهاء، قال ابن تيهية:" صارت -أي: الحيل- في عُرف الفقهاء إذا أُطلقت قُصد بها الحيل التي يُستحلُ بها المهحارم كححيل اليهود....)ج فبعد الوقوف على مفهوم الحيل يهكننا أن نوجز الفرق بين سلد الذرائع و الدحيل في الآتي:

اـ أن الحيل تتضهـن فتح الطريق إلى الهـحرمات بينها سلد الذرائع يوصد الباب أمام هذه الهـحرمات، فلا يقرب حماهـا قال ابن القيه:" وإذا تدبرت الشريعة وجدتها قد أتت بسد الذرائع إلى الهحر مـات، وذذك عكس باب الحيل الهوصلة إليها، فالحيل و سائل وأبواب إلى المهحرمات، و سد الذرائع عكس ذذلك، فبين البابين أعظهم تناقض، و الشارع حرم الذرائع، و إن لهم يقصد بها الهـحرم، لإفضائها إليـه؛ ثم قال نقلا عن شيخ الإسلام ابن تيهيـة: وتجويز الحيل يناقض سد الذرائع مناقضة ظاهرة، فإن الشسارع يسد الطريق إلى ذلك الهحرم بكل مهكن، والهـحتال يتوسل إليه بكل مهكن، و لهذا اعتبر الشارع في البيع و الصرف و النكاح و غير ها، شرووطا سد ببعضها التـذرع إلى الربا والزنا، و كهل بها مقصدود العقود، وله يهكن المهحتال الخروج منها في الظاهر. و من يريد الاحتيال على ما منـع الشارع منـه فيأتي بها مـع حيلة أخرى

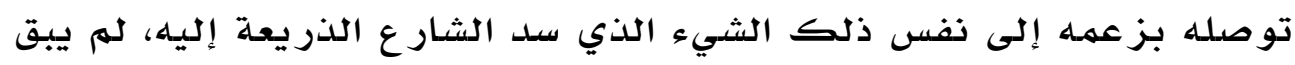

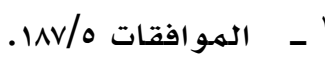

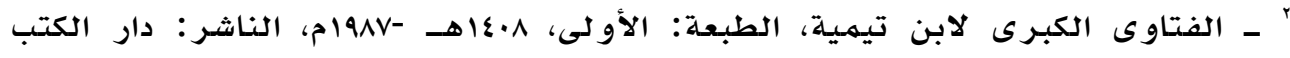

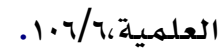
• ـ د. صالح بن سعود آل علي، الذرائع والحيل و موقف الشريعة منهما، مكتبـة العبيكان، ט " - إغاثة اللهفان، مكتبـة المعارف، الرياض، المهملكة العربية السعودية، تح: محمد حامد 
لتلك الشروط التي أتى بها فائدة ولا حقيقة، بل تبقى بهنزلة العبث و اللعب، و تطويل الطريق إلى الهقصود مـن غير فائدة.' r- الحيلهة تفضي إلى ابطال حكم شـرعي و تحويله إلى حكمم آخر، و بالتالي منـاقضدة لقواعد الشريعة و مقاصدها، بينهما سد الذرائع يتحقق بها مقصود الشار ع

بـ الهـنع في الذريعة راجـع إلى قوة التهمهة في التطرق إلى الهمهنوع بينها في الحيلة متوقف على وجود قصد المتحيل إلى سقوط الأحكام الشرعية أو تبديلها'

عـ الحيلة تجري في العقود، بينهـا تجري الذريعة في العقود و غيرها؟ ثانياً: الفرق بين الذرائع والمقدمات

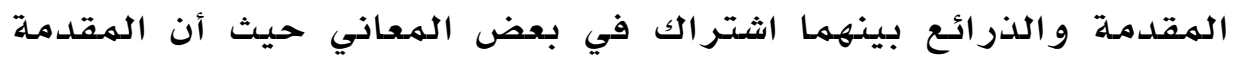
تشارك الذريعة في أنها سابقة عل المقصود و تشهل ما يتوقف عليه وجود الشيء، فيلزم مـن عدمها العدم ولا يلزم من وجودها وجود ما يتوقف عليها، فالوضوء مـثلا يتوقف عليـه وجود الصلاة كهقدمـة لها ويترتب على عدمـه العدم و لكن لا يلزم من وجوده وجود الصلاة، و لكن الذريعة أعم منها حيث أنها يترتب على وجودها الوجود قطعا أو احتهالا، ويترتب على

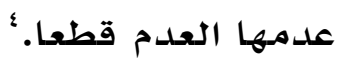

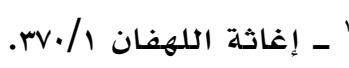

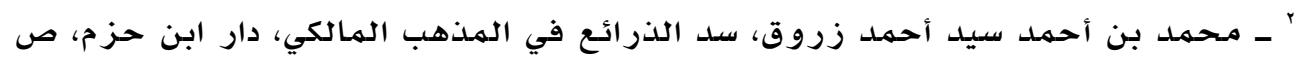




\section{المبحثُ الثاني: أقسام الذرائع وأحكامها وأدلة اعتبارها}

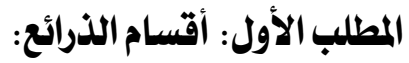

قسهم الأصوليون الذرائع تقسيهات عدة بناء على مدى ترتب الهفسلدة و على مدى تحققها، فجاءت تقسيهاتهم على هذا الاعتبار حاسهمة لوسائل الفسـاد المتحققة و المتوقعهة، فهن ذلك:

\section{القسم الأول: ما يؤدي إلى المفسدة قطعاً:}

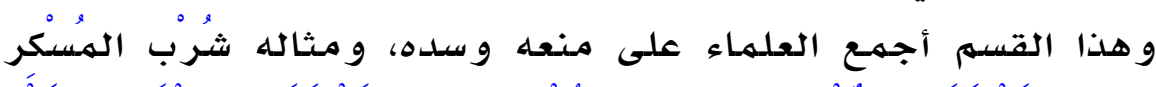

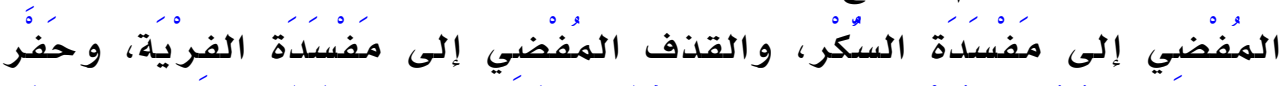

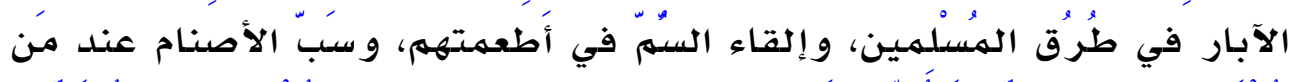

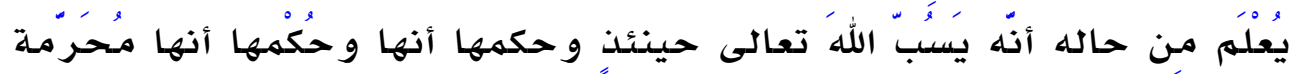

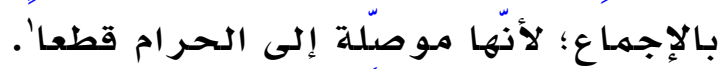

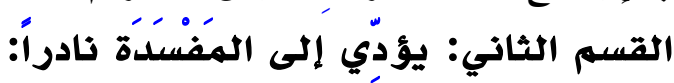

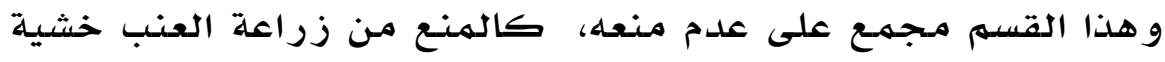
الخهمر، والمـنع مـن الهـجاورة في البيوت خشيـة الزنى، فلا تعتبـر مثل هذه الذرائع ؛ لأنها لا تو صل إلى الحر امَّ إلا نادرًا.

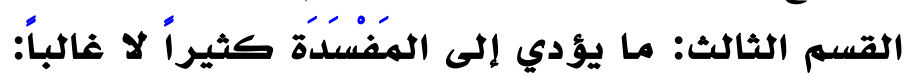

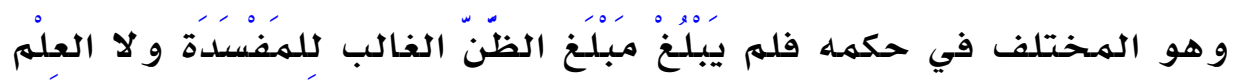

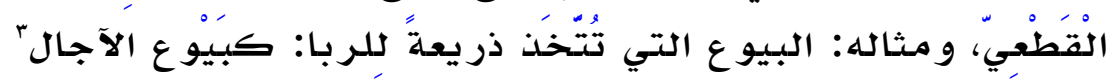

ـ ـ شهاب الدين القر افي، الفروق، الناشر : عالم الكتب، ب/Yr، ابن القيم، أعلام الهوقعين

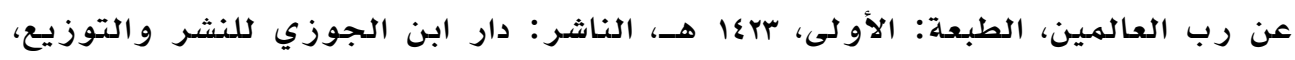

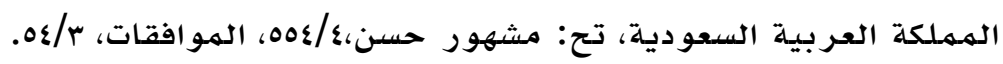

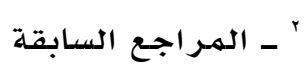

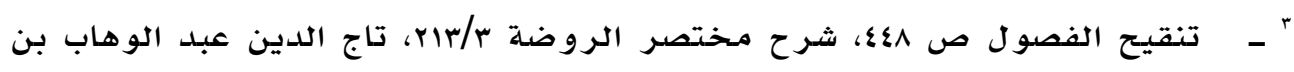

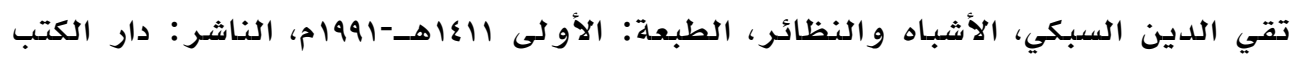

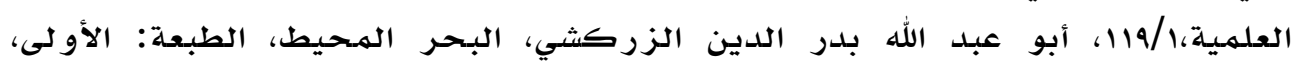

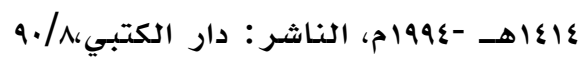




\section{المطلب الثاني: أدلة اعتبار سلد الذرائع عند المالكية:}

استدل المالكية على سد الذرائع بأدلة منها:

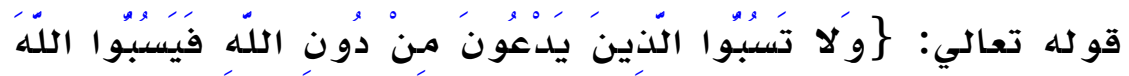

عَدواً بغَيْرِ عِلْمِ

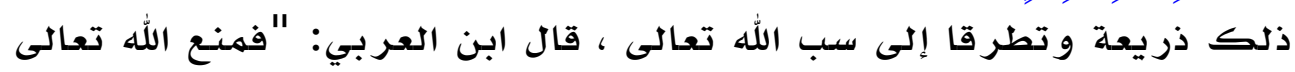
في كتابه أحدا أن يفعل فعلا جائزا يؤدي إلى محظور؛ وولأجل هذا تعلق

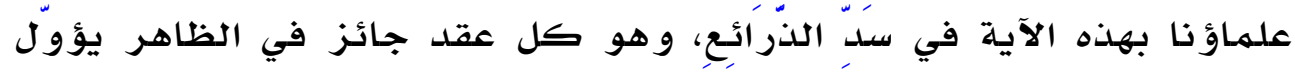
أو يهكن أن يتوصل بـه إلى محظظور"r وقال القرطبي: " في هذه الآية ضرب من الموادعة ودليل على وجوب الحكم بسلد الذرائع الب وقال ابن جزي: "واستدل الهالكية بهذا على سلد الذرائع "ا؛ و استدلوا بقو له تعالى:

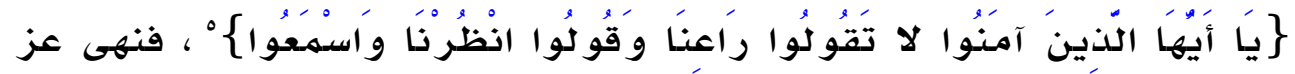

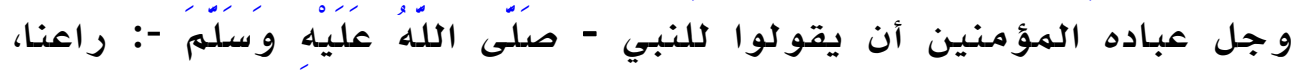
و هي كلمهة صحيحة معروفة في لغة العرب، معناها أرعني سهعك و فر غه لي لتعي قولي و تفهم عني؛ لأنها كلهة سب عند اليهود، فكانت تسب بها

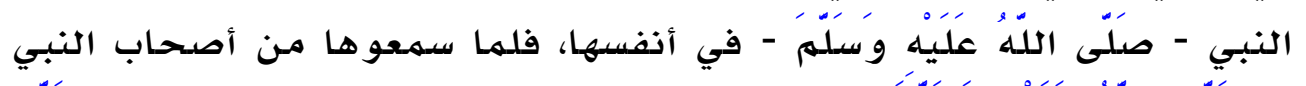

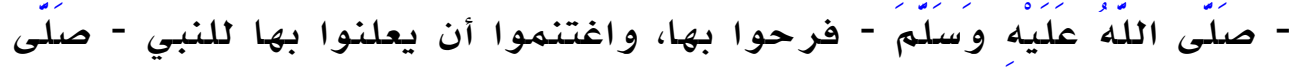

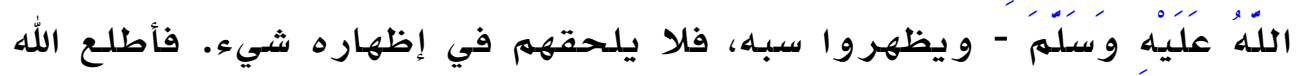
نبيـه و الهؤمنـين على ذلك، وذنهى عن الكلهـة، لئلا يكون ذلك ذريعة لليهود

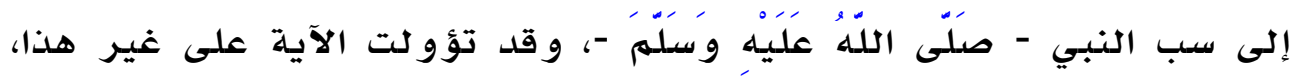

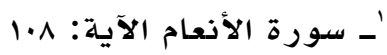

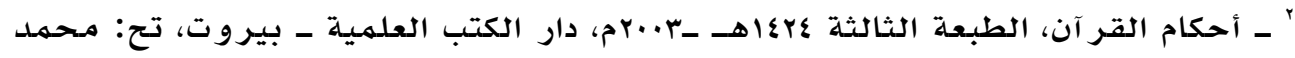

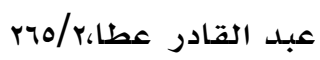

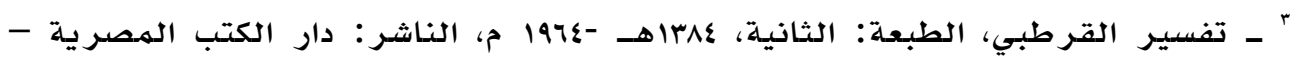

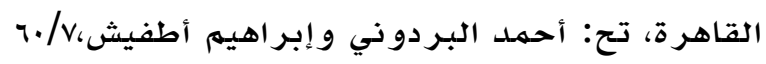

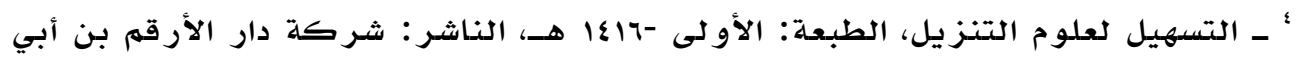

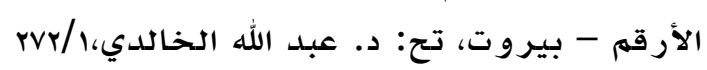

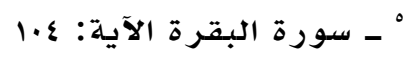




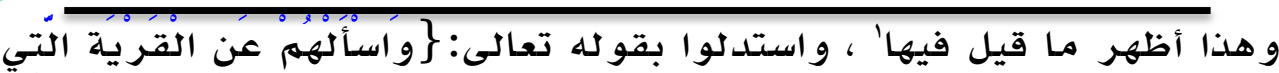

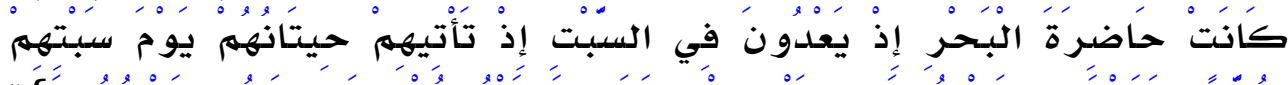

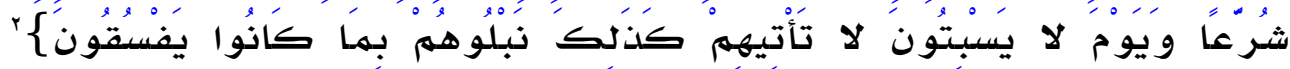
و جـه الدليل مـن هذه الآيـات على وجوب المـنع من الذرائع: أن الله حرم على اليهود الاصطياد يوم السبت ابتلاء لهه، و ذلك أن اليهود قالوا لهوسى حين أمرهم بالجمعة و أخبرهم بفضلها: كيف تأمر بالجمعلة وتفضلها على سـائر الأيـام والسبـت أفضل الأيام كلها، لأن الله تعالى خلق السهاوات و الأرض والأوقات في ستة أيام، وسبت لله كل شيء مطيعا يوم السبـ، فقال الله عز وجل لهوسى: دعهم ووما اختاروه، و لا يصيدون فيه سهكا و لا غيره و لا يعملون فيه شيئا، فكانت الحيتان تأتيهم يوم السبت شارعة ظاهرة كما قال الله تعالى، وتغيب عنهم سـائر الأيـام فلا يصلون إليها إلا بالاصطياد والعناء، فكانوا يسلدون عليها المسالك يوم السبت ويأخذونها في سـائر الأيام، و يقولون: لا نفعل الاصطياد الذي نهينا عنه في يوم السبـ، و إنها نفعله في غيره، فعاقبهم الله على فعلهم ذلك، لأنه ذريعة تلاصطياد الذي نهوا عنه وإن له يكن اصطيادا على الحقيقة - بأن مسخهه قردة وخنازير - كها أخبر تعالى في كتابهاr، وقال ابن العربي : "قال علماؤنا هذه الآية أصل من أصول اثبات الذرائع التي انفرد بها مالك" ؛ ومن ومن

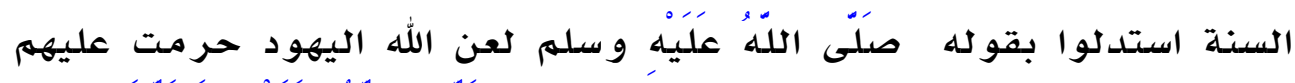

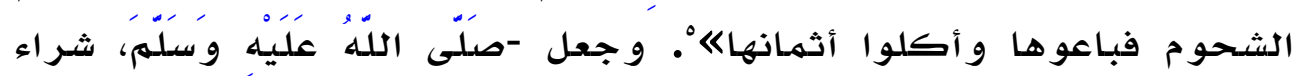
الصدقة بالثمـن كالعودة فيها بغير ثمـن، لافقال لعهر بن الخطاب في الفرس الذي حهل عليه في سبيل الله فأراد شر اءه لها أضاعه صاحبـه و أراد

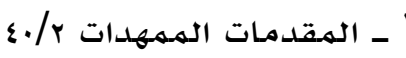

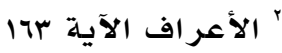

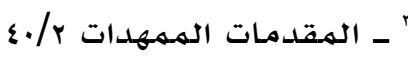

$$
\begin{aligned}
& \text { ؛ ـ أحكام القر آنץ/اسب. }
\end{aligned}
$$

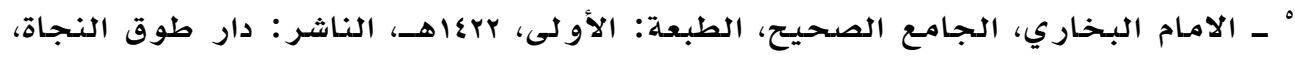

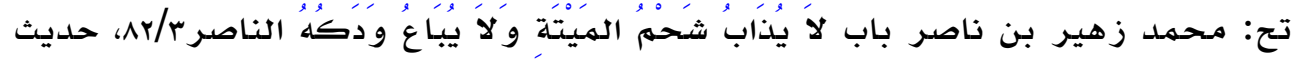


بيعـا: لا لا تشتره و إن أعطاكه بلدرهم واحد، فإن العائد في صدقته

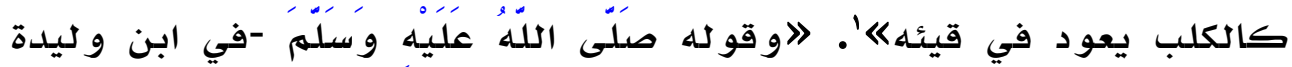
زمعة لعبد بن زمعة: هو لك يا عبد بن زمعة فألحقه بأبيه زمعة، وقال: الولد للفراش و للعاهر الحجر • وقال لأخته سودة بنت زمعة زوجته:

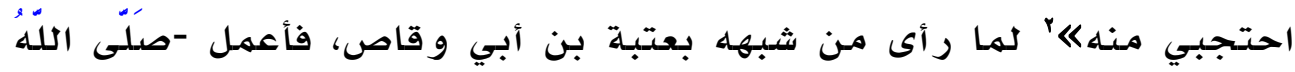

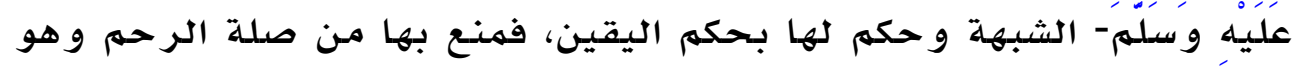

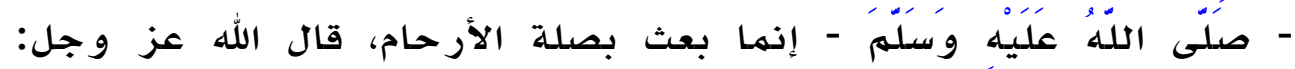

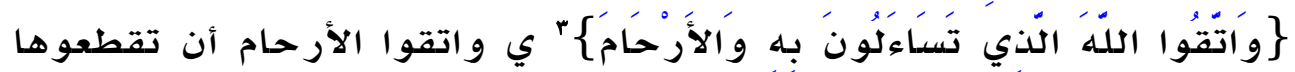

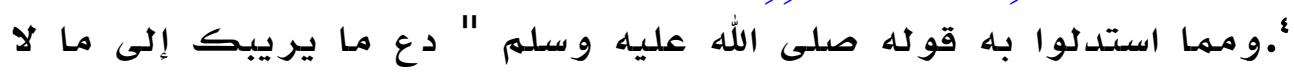

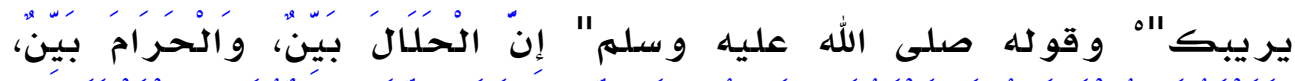

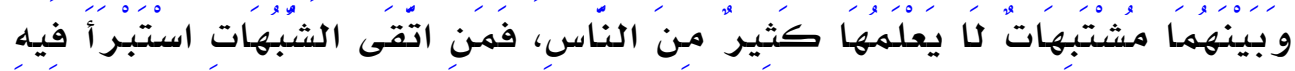

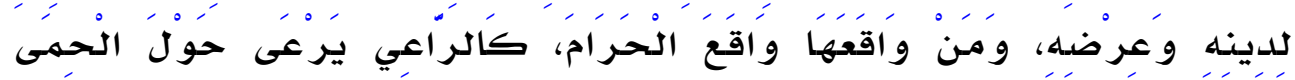

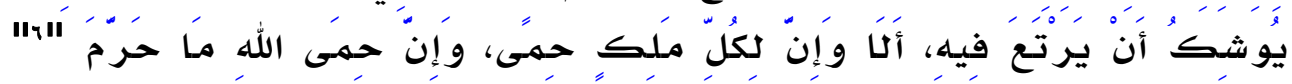

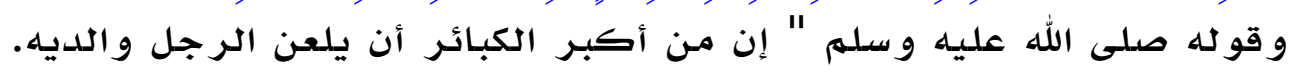
قيل: يا رسول الله، وكيف يلعن الرجل والديه؟ قال: يسب الرجل أبا الرجل، فيسب أباه و يسب أمـه). قال ابن بطال: "هذا الحديث أصل في قطع الذذر ائع

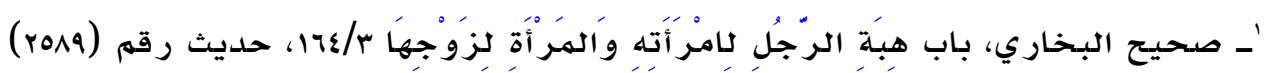

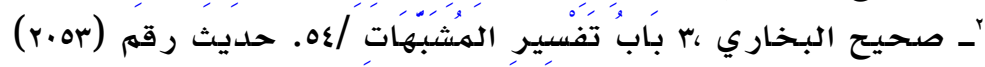

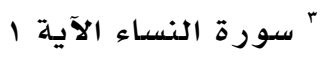

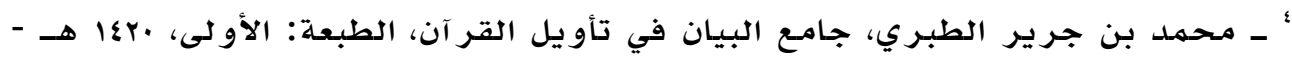
or./V، r...

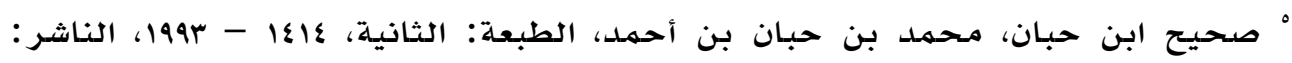

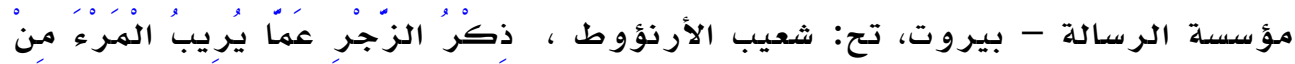

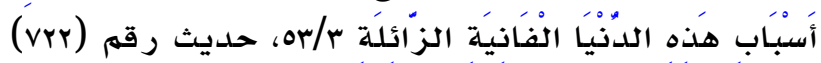

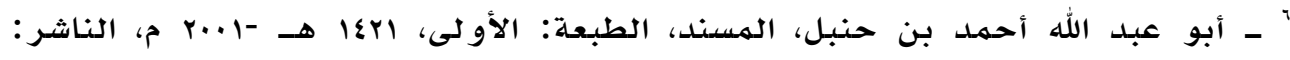

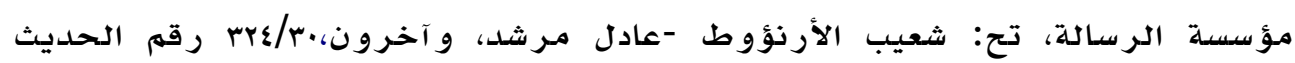

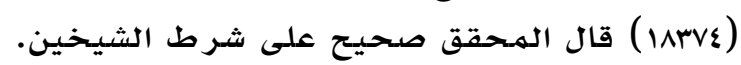

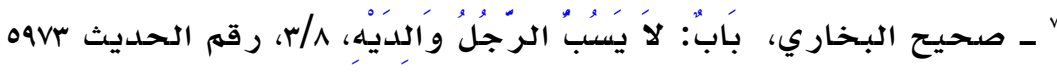




\section{المبحثُ الرابع: تطبيقات سل الذرائع في باب النكاح عند المالكية:}

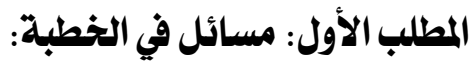

\section{المسالة الأولى: النظر إلى المراة بقصد خطبتها:}

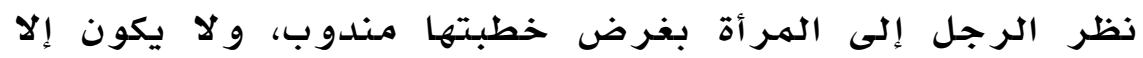

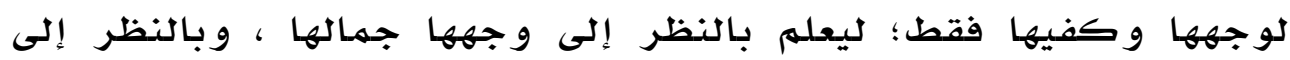

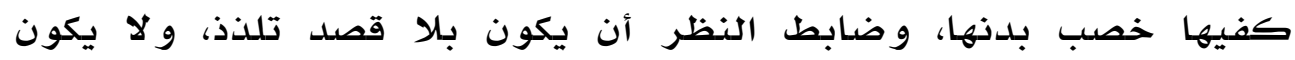

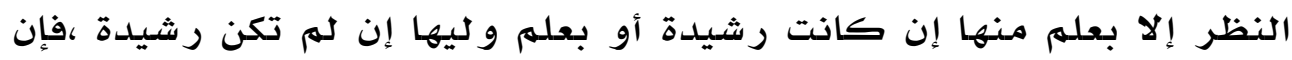

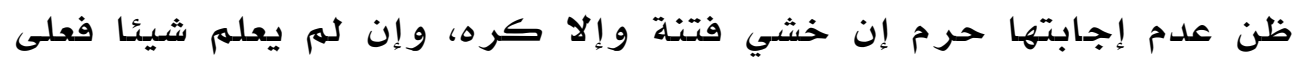

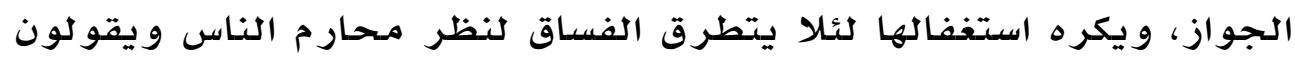
نحن خطاب'، وروى محمد بن يحيى: لا بأس أن ينظر إليها و عليها ثيابها،

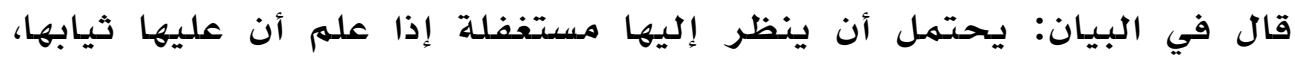

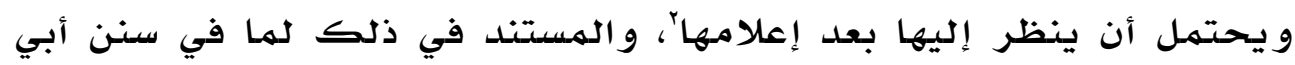

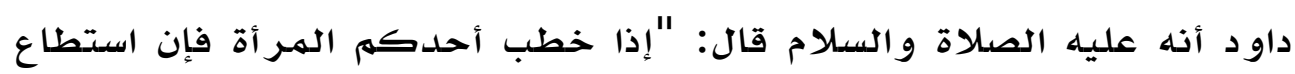

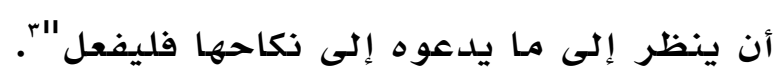

وجه حماية الذرائع في عدم جواز استغفال المخطوبة حال إرادة النئ النظر إليها:

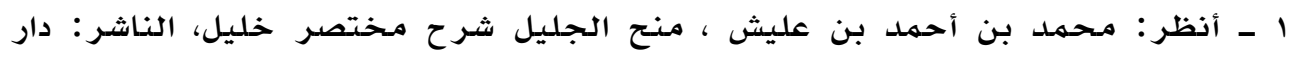

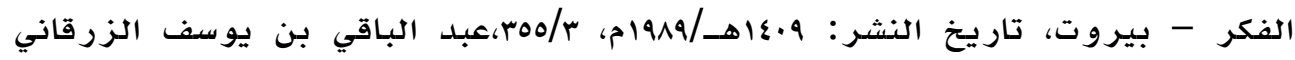

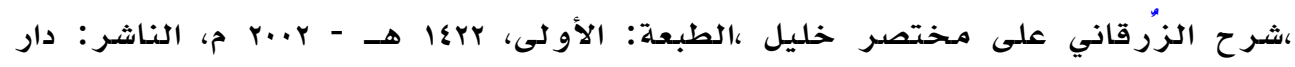

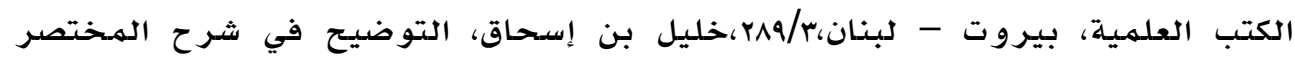

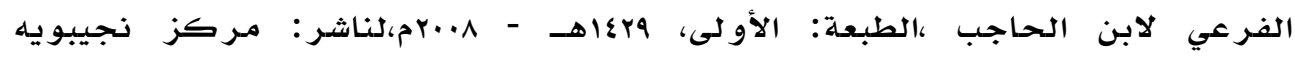

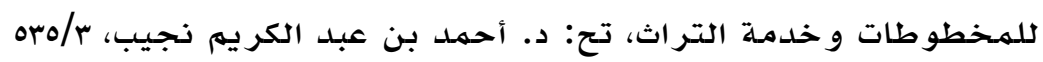

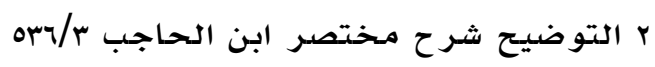

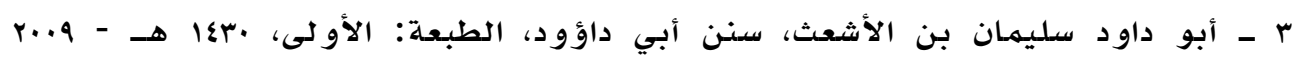

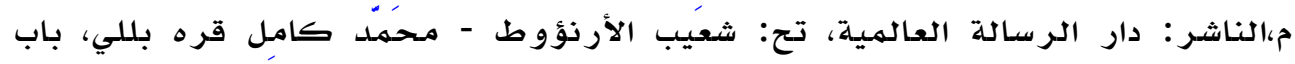

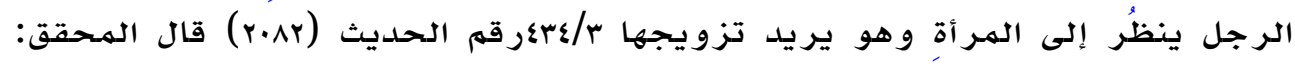
rร.

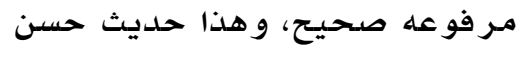


إعلام الهخطوبة أو إعلام وليها عند إرادة النظر إليها وعدم جواز استغفالها سدا لذريعة أن يتطرق الفساق لنظر محارم الناس ويقولون ذحن خطاب'

المسالة الثانية: فساد نكاح من عقد على امراة مخطوبة لغيره: الخطبة على الخطبة لها حالتان: الأولى: أن ترضى بالأول و تركن إليـه الثانية: أن لا تنعم له وتهر انهن إليه. الحالة الأو لى اضطربت فيها الأقوال وتخالفت الآراء: القول الأول: فسخ العقد بعد الدخول وقبله ويكون فيه الصداق الهسهى و ذلك إذا حصل مـ الرضا والركون تسهية الصداق، وثبت ذلك حتى عُلم، وهو ظاهر الهذهب وقول ابن نافع، وظاهر قول مـالك في الهوطأ،

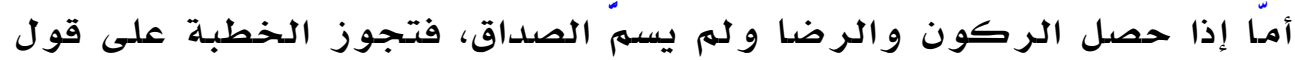
ابن نافع '، وتمنع على قول مطرف وابن الهاجشون وابن القاسهم وابن وهب

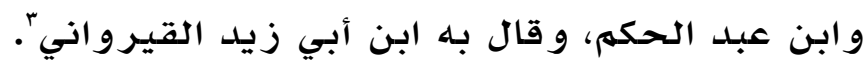
الثاني: غذم الفستخ ويؤدب فاعله، و هو قول ابن القاسهم و أشهب. الثانث: إذا عقد فليتب ويعرضها على الخاطب، فإن حلله كان لـه ذلك مخرجاً، وإن أبى فليفارقها، وهو قول ابن وهب، وقال ابن القاسهر: إن له يحلله فليستغفر الله و لا شيء عليـه. الر ابع: إذا كان الخاطب فاسدا في حاله: فقد روي عن ابن القاسهم أنه قال الرجل الهسخوط الفاسد في حاله كله يخطب امـرأة فترضى بـه وسهيا

ـ شمس الدين أبو عبد الله محمد بن محمد الحطاب، مواهب الجليل في شرح مختصر

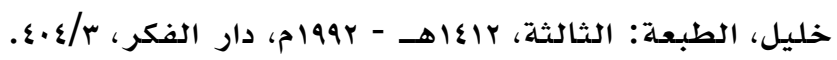
r ـ أبو الو ليد محكمد بن أحمد بن رشد القرطبي ،البيان والتحصيل ، الطبعة: الثانية،

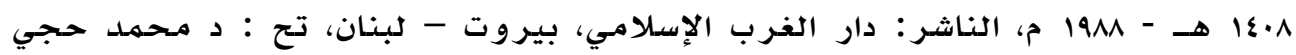

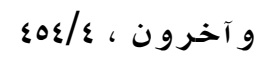

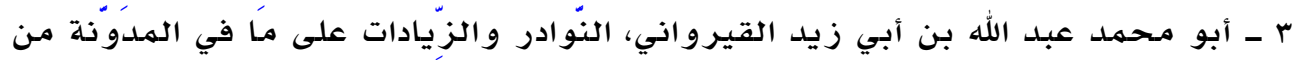

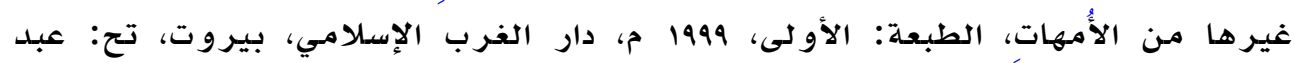

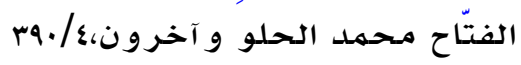


الصداق و لهم يبق إلا العقد، فيأتي رجل مـرضي حسن الحسال فيخطبها، هل يقال فيه ذلكء قال لو كنت وليها لأمـرتها بنكاح هذا الهرضي، و لا أرى على مـن دخل في ذلك شيئًا -إن شاء الله -، ولا أرى الححديث إلا في الرجلين الهتقاربين، فأما فاسق وصالح فلا'؛ لأن في نكاحها تخليص لها من فسـقهـ

وتحصيل المدهب في ذلك فسـخ النكاح قبل الدخول استحبـابا لأنه تعدى مـا ندب إليه وبئس ما صنـع فإن دخل بها مضى النكاح وله يفستخ لأنها امر أة لهم يعقد عليها غيرهّا. الحالة الثانية: إذا ابتدأ الخطبة، أو وعد و عداً معلقًا من غير إجابـة و لا ركون، فجاء غيره فخطب، فإن هذا لا يمنـع؛ لأن الناس لو منعوا من أن يخطبوا مـن قد خطبت، أو روسلت، أو كلهـ، لشق عليهم ووضاق، و أدى إلى أن لا يخطب أحدٌ امر أة إلا بعد أن يسأل و يبحث هل راسلها غيره أو ابتدأ خطبتها، ووفي ذلك من الضيق و الحرج ما يوضدع عن الناس و لا يؤخذون به، و بهثله وردت السنة في حديث فاطمة بنت قيس لهما جاءت النبي - أنها صلى الله عليه وسلهم - أعلهته أن أبـا جهم وومعاوية خطباها فقال رسول الله - صلى الله عليه وسلهم -: "أما أبو جهم فلا يضع عصداه عن عاتقه، وأما معاوية فصعلوك لا مال له، و لكن انكحي أسـامة بن زيدء"، فلهم ينكر اجتهاعهما عليها في الخطبة وخطب عليها لآخر، ومثله حليث عمر بن

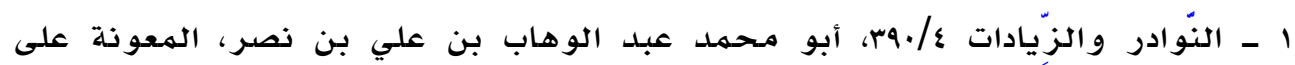

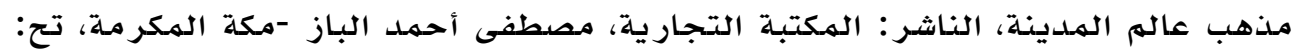

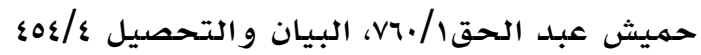

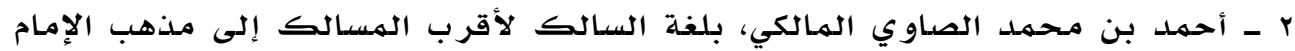

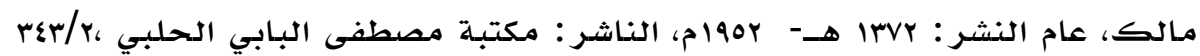
r - أبو عمـر يوسف بن عبد البر، الكافي في فقه أهل المدينة، الطبعة: الثانية،

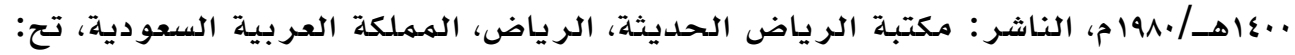

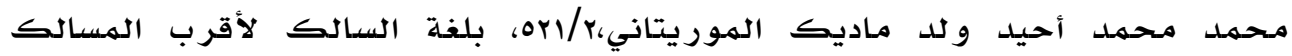

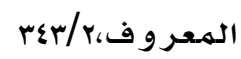

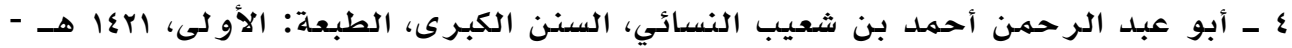
r

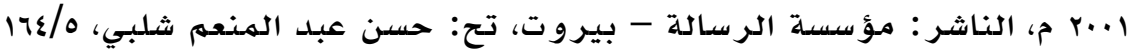


الخطاب - رضي الله عنه - لها خطب امـرأة لابنهل عبد الله ولهـروان وغيره، ثهم خطبها لنفسـ معهم فقادت الهـر أة: أجـاد أمير الهؤمنين أم هازل؟ قال: بل جاد، فقادت: قد أنكحتك" ، فاستجاز عمر لنفسه أن يخطبها معهم لها لهم يكن مـن جهتها إنعام لواحد منهم و لا إجابة و لا ركون و لا و عد' وجه حماية الذريعة في القول بالفسخ قبل الدخول: يظهر وجهه حماية الذريعة في تحريهم الخطبـة على الخطبـة لكونه ذريعة إلى الإفساد على الناس وإدخال الأذى عليهم لأنه لا يشاء أحد أن يفسد على غيره و يؤذيه إلا تر كه يخطب ويبعث و يجتهد حتى إذا له يبق إلا الفراغ جاء فأفسد عليـ، فوجب حسله الباب بإبطال مـا أدى إلى هذا الفعل ليرتدع من يفعل ذلك على ألا يعود لهثله كها وجب مثله في التلقيّ وغيره و لذا نهى صلى الله عليه وسلهم عن ذلك في الحديث الذي رواه البخخاري

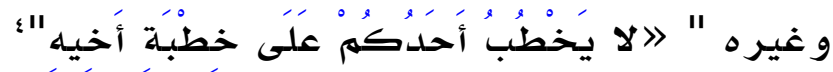
الاطلب الثاني: مسائل في أركان النكاح وشرورطة المسألة الأوذى: اشتراط الولي في النكاح: الولي شرط في النكاح عند الهالكية بلا خلاف احتيـاطا للفروج و سدا لهذه الذرائع:

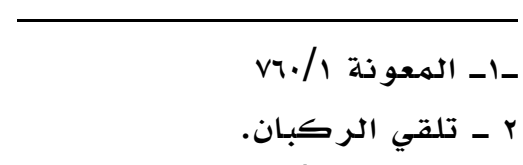

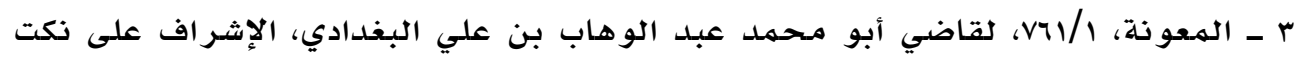

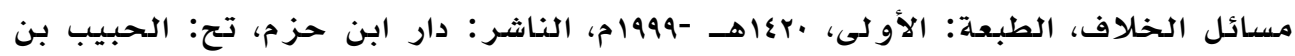

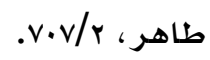

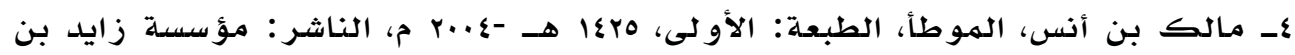

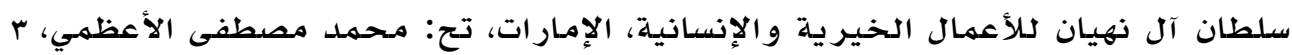

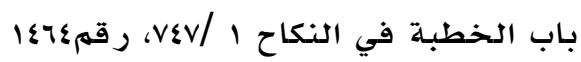

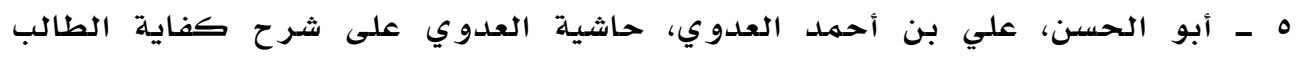

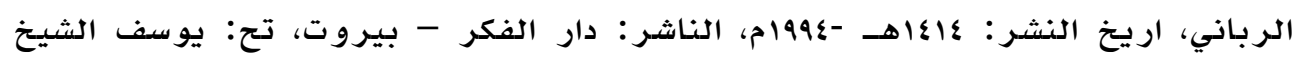

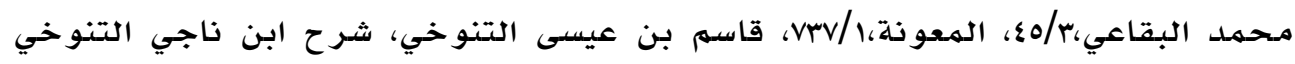

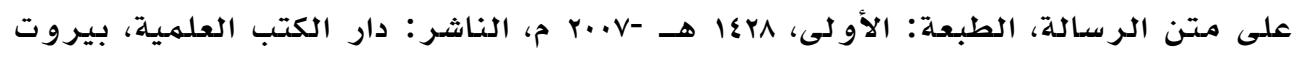
$r \leqslant T$

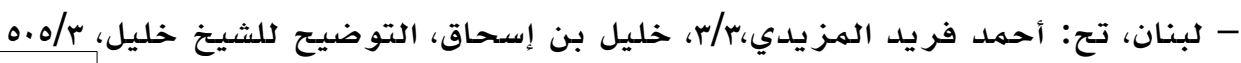


اـ الخشيـة مـن أن تحمل الهـرأة شهوة النكاح وميلها إلى الرجال على التسر ع إلى وضع نفسها في غير كفؤ فتلحق عارًا بأو ليائها rـ لدفـع الهعرة التي تلحق الولي إن زوجت الهمر أة نفسها' وهذا كلـه راجـع

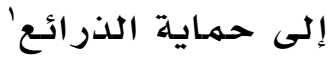

المسائة الثانية: ضياع صداق البكر قبل أن تقبضه:

وذلك إذا دفح الزوج الصداق إلى أبي البكر أو إلى وصيها ثه ادعوا ضياعد فها الحكمى

في المسألة تفصيل من حيث قبضهما الصداق ببينة وبغير بينة، وومن حيث دعوى ضياعه قبل البناء أو بعده، فإن كان القبض ببينهة: فمشهور الهذهب أن ما قبضوا ببينـة وزعموا أنه ضـاع، أن ضياعه مـن الابنة، و ليس على الزوج من الضياع شيء ولا على الأب أو الوصي، ويدخل الزوج بـامر أتهل

وخالف أشهب وابن وهب وقالا: لا يبرأ الزوج مـن الههر بإقرار

الأب بقبضه إن ادعى تلفه' و إن كان القبض بغير بينة: فقو لان ' أحوطهما عدم براءة الزوج ودفعه ثانية؛ لأن الأب يتهم أن يكون وضع الصداق من غير طلاق؛ و لأن مـن حق الزوجة ألا تسلهم سلعتها إلا بقبض ثمنها، وحكى

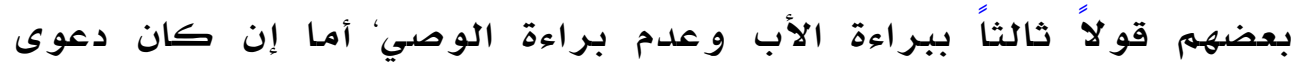
ضياعه بعد البناء وقد أقر الأب بقبضه، فاتفق أرباب المذهب على براءة

1 ـ مناهج التحصيل r/r/r/

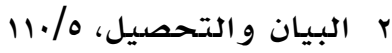

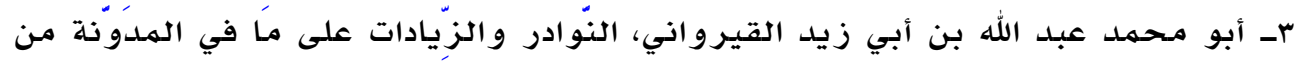

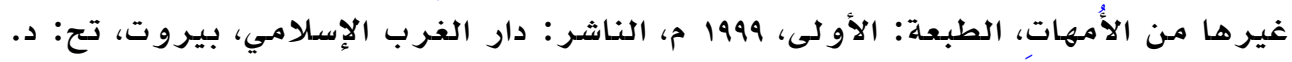

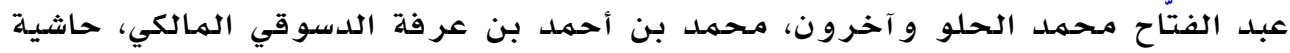

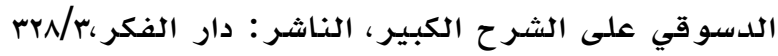


الزوج منه، وهل يحلف الأب ؟ خلاف، وقد ذهب ابن العطار و غيره بوجوب

ذ'لك'

\section{وجه حماية الذريعة في إلزام الزوج بالمهر ثانية إن ضاع من الأب أو الوصي بعد إقرار هما بالقبض:}

و جـه إلزام الزوج بالههر ثانية إن ضاع من الأب أو الوصي بعد إقرارهها

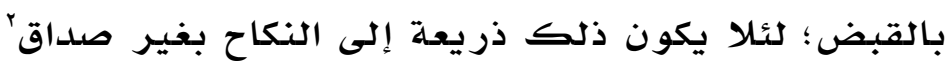

\section{المسالة الثالثة: الأجل في الصداق:}

اتفق أهل الهذهب على تحديد الأجل إن كان بعض الههر مؤجلا فإن أجسل لأجل غير مسهى أو إلى أن تطلبـه أو إلى يسـار الزوج ونحو ذلك من إن إن الأجل غير الهؤقت فإن مـالكا يفسخه قبل البناء، ويهضيه بعده ، وترد الهر أة إلى صداق مثلهها معجلاً" كله، إلا أن يكون صداق مثلها أقل من الهعجل فلا ينقص منـه، أو أكثر من المعجل والمؤجل فتوفي تمام ذلك،

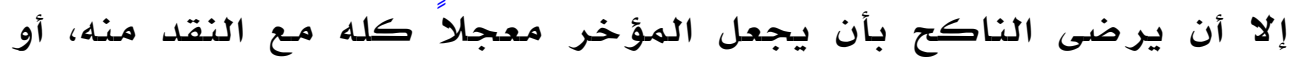
ترضى الهـر أة بوضعـه فيهضي النكاح، فلا يفستخ لا قبل البناء و لا بعده، و كره الإمـام مالك وأصحابه المؤخر من المهر ، ووكان مالك يقول: إنها الصداق فيها مضى ناجز كله ؛ فإن وقع مؤجلا فالأحب إلى مالك ألا

يطول الأجل، فإذا طال الأجل فهل يفسـ العقد لأجل ذلك؟ مؤ ذكر ابن الهواز عن ابن القاسهم تأخير الأجل إلى السنتين و الأربع. وذُكر الهر عن ابن و هب إلى السنـة، ثم حكي عن ابن وهب أنه قال: لا يفسخ النكاح إلا أن يزيد الأجل إلى أكثر من العشرين، وحكي عن ابن القاسهم أنه يفسخه

1 - عبد الباقي بن يوسف بن أحمد الزرقاني، شرح الزُرقاني على مختصر خليل،

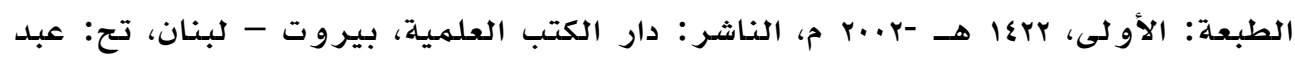

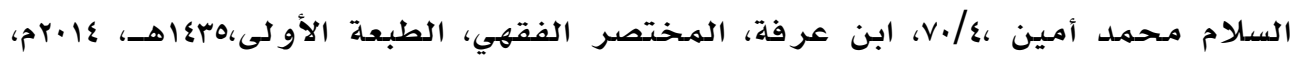

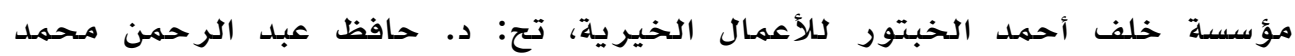

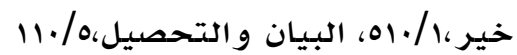

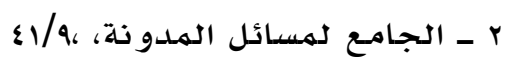


إلى الأربعين فها فوق، ثم حكي أنه إنها يفسخه إلى الخهسين و الستين؛

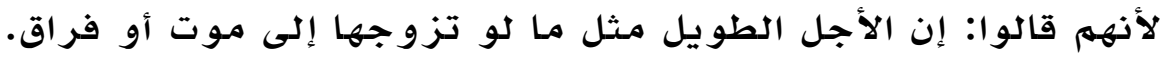

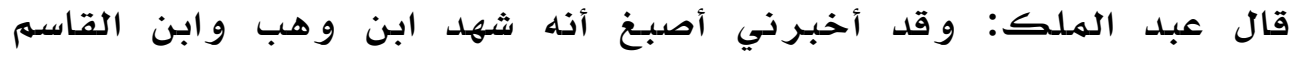

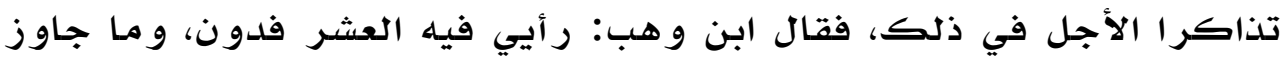

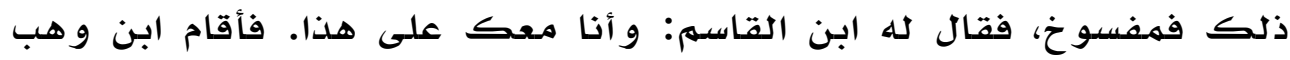

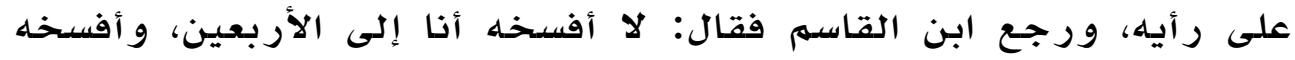

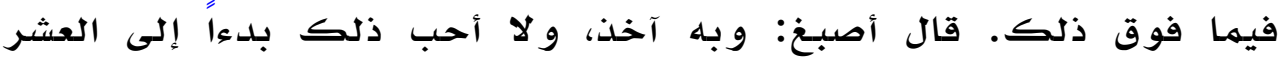
ونحوها، وقد شهدت أشهب زوج ابنته وجعل مؤخر مهر ها إلى اثنتي عشرة

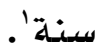

\section{وجه حماية الذريعة في كراهة الأجل في الصداق:}

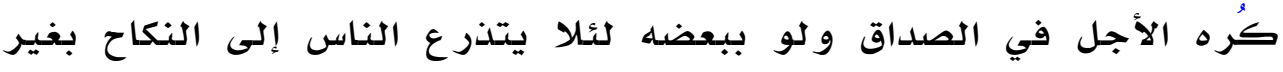

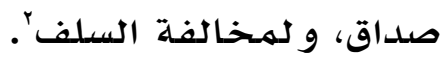

\section{المسالة الرابعة: هبة المر أة صداقها لزوجها قبل البناء} إذا وهبت الزوجة مهر ها لزوجها و لو قبل البناء جاز ذلك؛ لقو له تعالى:

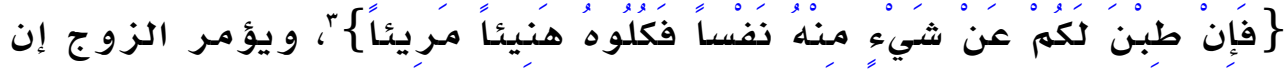
وهبته إياه قبل البناء ألا يبني حتى يقدم ربع دين دينار خوف أن يكونا عقدا

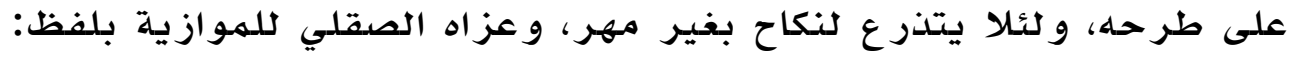

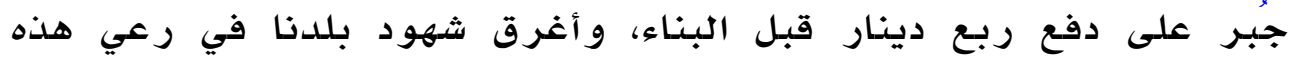

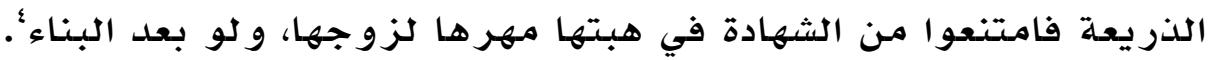

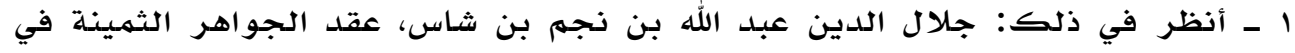

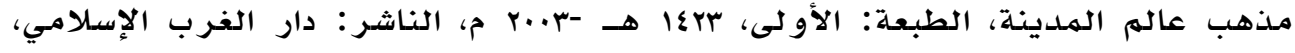

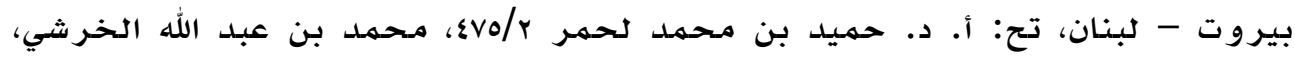

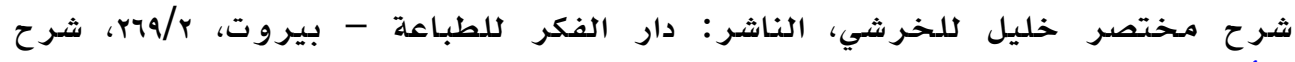

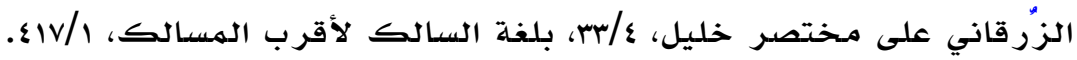

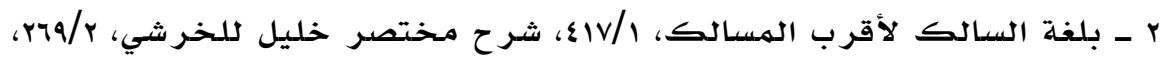


وجه حماية الذريعة في أنا يبني من وهبته زوجته مهرها حتى يقدم ربع

الذريعـة الهحميـة في عدم جواز البناء بزوجته التي وهبته مهر ها حتى

يقدم ربع دينار ؛ لئلا يخلو النكاح من صداق، قاله الشيخ الصاوي و غيرها. المساكة الخامسة: انضمام عقد البيع أو غيرهُ إلى عقد نكاح: صورة الهسألة أن يدفع الزوج للهمرأة دارا على أن يتزوجها وتدفع لله مـائة أو تقع هذه الصدورة مـع و ليها، فاختلف أرباب المدهب في جواز العقد ابتداء على قو لين:

القول الأول: أن العقد الواقع على هذا الوجه صحيح، لا وههم فيه، وهو قول أشهب ووجه قو له إنه ليس في ذلك أكثر من الجهالة بهقدار الههر، و ذلك لا يهنع صحة العقد، كها لو تزو جها على حكم زيدّا. القول الثاني: أن العقد لا يجوز، فإن وقع ونزل هل يفيته العقد أو لا يفيته إلا الدخولى فالمدهب على قو لين قائمهة من "الهـدو ذلة" الأول: الفسخخ قبل البنـاء: وهو مشهور المدذهب سواء سهى لها مهرا او لهم يسه" ، وسواء بقي بعد طرح قيهة البيع مـا يستحل بـه البضع أو له يبق، وقول الإمام في المدونة " لا يجتهـع في صفقة واحدة نكاح وبيع" و ذلك للتنافر بين العقدين وتضادهما؛ لكون البيع مبنياً على الهكايسة و الهشاححة، والنكاح مبنيًا على الهقاربة و الهسـامحة ، و ولأن النكاح عقد" مخصوص من سـائر عقود المعاوضة بأحكام لا توجد في غيره، فوجب ألا يضهم إليه عقد غيره هالصرف و والقراض، و ولأنه يجوز أن يكون العوض في مقابلة البيع فيعرو البضع من عوض، و تكون ذريعةً إلى الإباحة في إسقاط الههر ؛ و لأنه لا يلدرى ما يخص البضع من ذلك فيصير نكاحاً مـجهو لاء

$$
\text { 1 - بلغة السالك لأقرب المسالك وrY/1، }
$$
r - كالقرض أو القراض أو الشركة أو الجعالة أو الصرف أو المساقاة

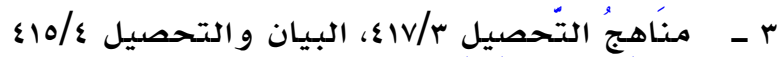

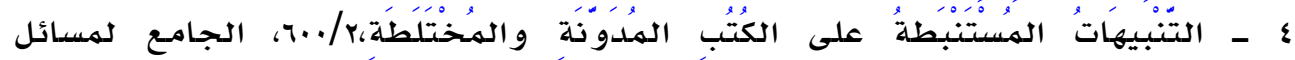

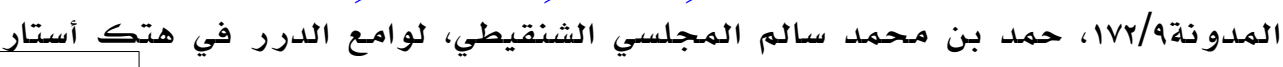


الثاني: يكره ابتداء حماية للذرائع، فإذا وقع نظر فيه: فإن له يكن فيها أعطى الزوج على ما أعطت الهـرأة فضل يكون صداقًا لهم يجز، ووفسخ قبل الدخول ومضى بعده بصداق الهثل، وإن بقي مها يعطي الزوج ربع دينارٍ فصاعداً جاز النكاح، و هو قول مطرف، وقيل فضل بائن كثير لا يقارب أن يستغرقه ما أعطت المر أة، جاز النكاح و لهم يفسخ، وهو قول ابن الهاجشون وقول مطرف أظهر ؛ لأن التقويهم يكشف صححة العقد من فساده'. ووجه قولهم: إن الهــع مـن خيفة أن يعرو النكاح من عوض، فإذا أمن

ذلك جاز

وجه حماية الذريعة في فسخ النكاح إذا انضم له عقد بيع ونحوه: الهـافة من أن يكون ذلك ذريعة إلى إباحة وإسقاط الههر، فيكون الفرج موهوبا بغير صداق، وإن كان فيما أعطى الزوج فضل كثير على أنى

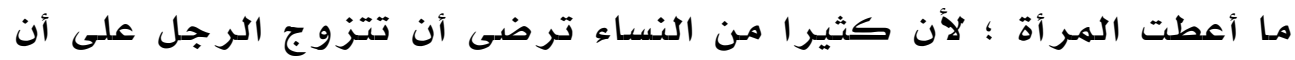
تعطيه لرغبتها فيه لشرفه وحاله أو لكثرة يساره أو ما أشبه ذلك، فيخشى إن صـح الأمـر مـن هذين أن لا يصح مـن غير هماسالهسألة السادسة: فسن النكاح إن تم بلا شهود: الشهود ركن في عقد النكاح يفسخ بعد الدخول إن تم بلاه، ويكون الفستخ بطلقة بائنة ع وجله حماية الذريعة فستخ النكاح إن تم بلا شهود: يفستخ النكاح إن تم بـلا شهود سلدا للذريعة؛ إذ لا يشاء اثنان الاجتماع على فساد

المختصر، الطبعة: الأولى، بrعا هـ - r.10 م، الناشر: دار الرضوان، نواكشوط-

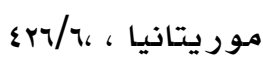

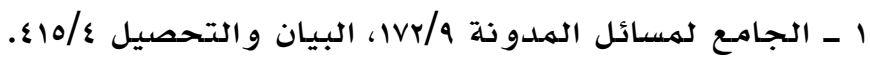

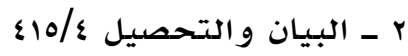

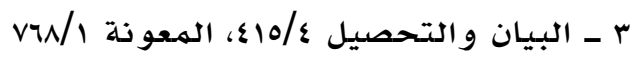

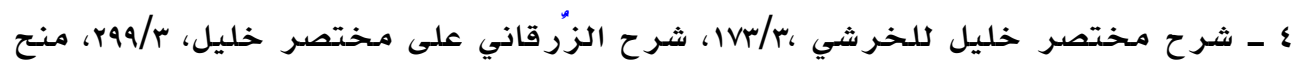
$\Gamma \leqslant \Lambda$

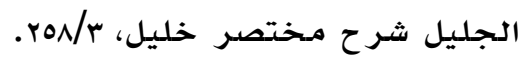


في خلوة إلا فعلا و ادعيا سبق عقد بلا إشهاد، فيرتفع حد الزنا والتعزير، فإن أراد معاشـرتها فلا بـ له مـن عقد جديد شرعي، وتبقى له طلقتان'

\section{المسالة السابعة: الإقرار بالزوجية بلا بينة:}

ووروة ذلك إذا أقرت امرأة بزوج أو أقر رجل بزوجة وصدق الآخر صاحبه: قال أهل المدينة: إن كانا غريبين طارئين قبل قولهما و لهم يكلفا بينـة على عقد الذكاح، وإن كانا حاضرين مقيمين لهم يقبل قو لهما إلا ببينـة على عقد النكاح، وقال أهل العراق: قولهما مقبول على كل حال، كانا

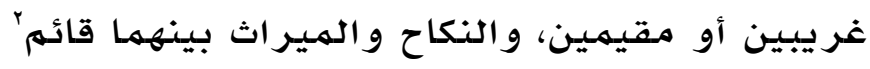

وجه حماية الذريعة في عدم قبول قول المقيمين المدعين الزوجية إلا بينة:

يظهر وجه حماية الذريعة في عدم قبول قول الهقيهين المدلين

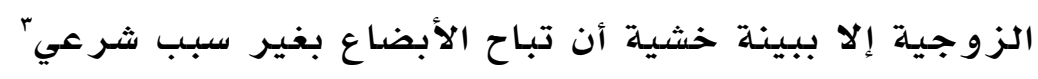

\section{المسالة الثامنة: ذكاح السر:}

اختلف في المـذهب في حقيقة نكاح السر و مفهومـه، فقيل: هو الذي يؤمـر

الشهود بكتهـه و إن كثروا، قال صاحب النوادر:كل نكاح استكتهته الشهود و إن كثروا أو عقد على وجه الاستسرار، فهو من نكاح السر. وإذا سألوا الشهود أن يكتهموا ذلك مـن امر أة له أخرى، أو يكتهوا ذلك في منزل التي نكح، ويظهروه في غيره، أو يظهروه في المنزل ويكتهوه في غيره، أو يكتهوه بثلاثة أيام أو نحوها، فذلك كله من نكاح السرء

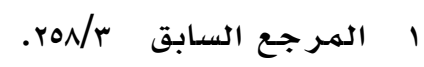

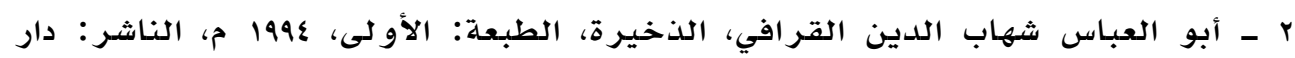

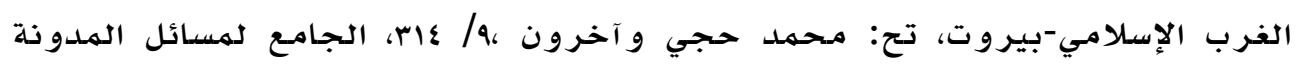
orq/ rl ب - م أنظر : المر جعين السـابقين.

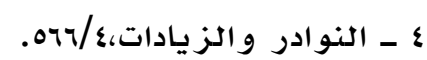




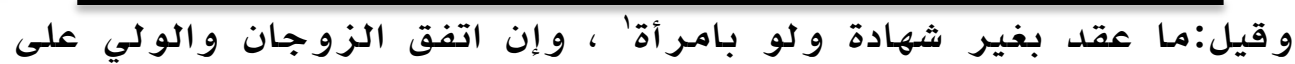

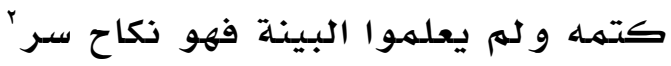

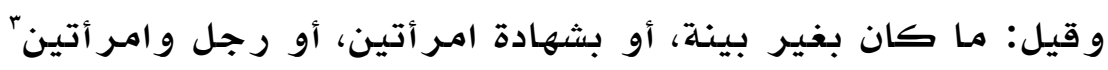

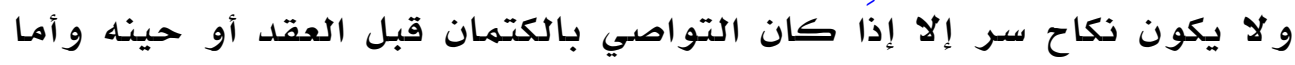

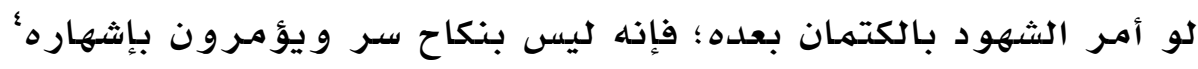
حكمه:

ا- الفسـخ بطلقة ما لهم يدخل ويطل؛ فإن دخل وطال فلا فسـخ؛ لحصول

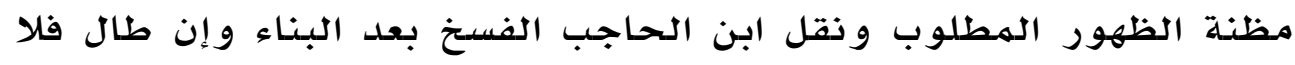
وجود له في المذهب، و كذلك يفسخ إذا نكح بشرط ألا تأتيه أو يأتيها إلا والا

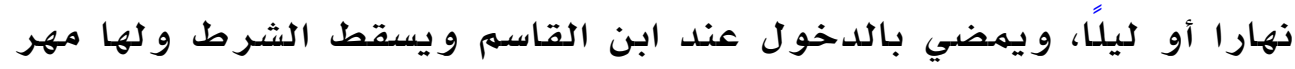
الهثل

r- يعاقب الزوجان و الشهود مـع العمد لا الجهل و إن لهم يحصل دخول

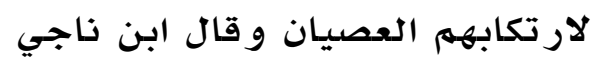

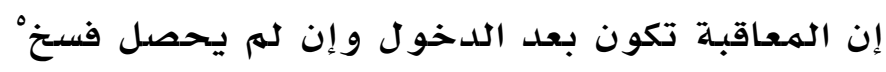
وجه حماية الذريعة في المنع من نكاح السر:

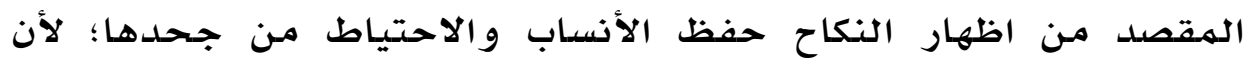

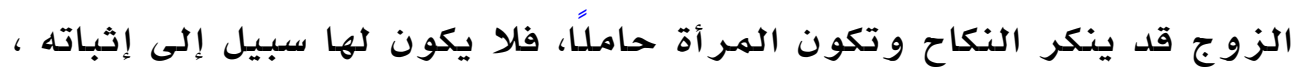

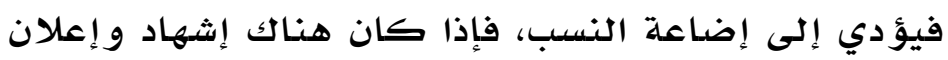

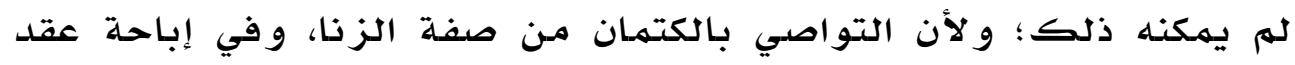

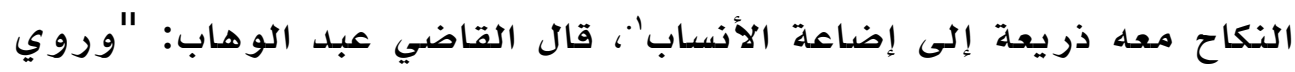

$$
\begin{aligned}
& \text { ا }
\end{aligned}
$$

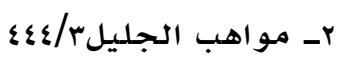

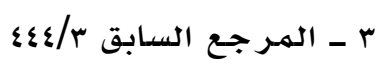

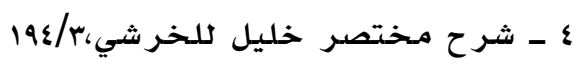

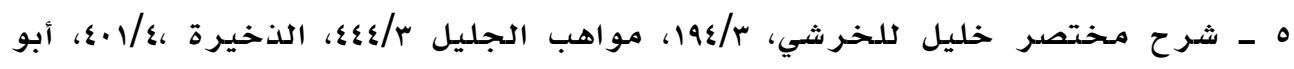

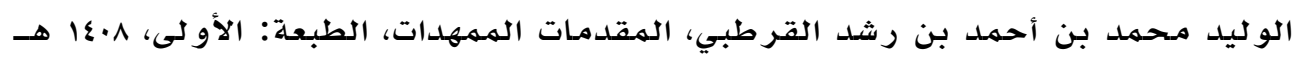

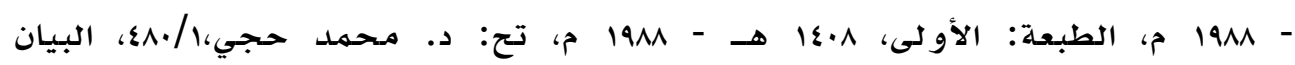
ro. و التحصيل \& 
أذه -صلى الله عليه وسلهم-نهى عن نكاح السر'، ولأن الزنا لها كان يقع مستسراً مكتتمكاً وجب أن يقع النكاح على خلافه وإلا كان ذريعة إلى إنى إباحته، لأن كل من وجل مـع امر أة ادعى أنها زوجته وأن شهوده غيب، فوجب حسهم الباب فيـا

\section{المسالة التاسعة: استبراء الهغيرة التي تطيق الوطء:}

عدة الهطلقة الهطيقة للوطء ثلاثة أشهر عملا بقو له تعالى (روآلكائي

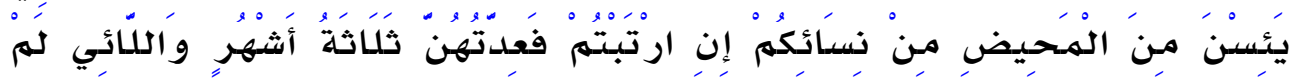

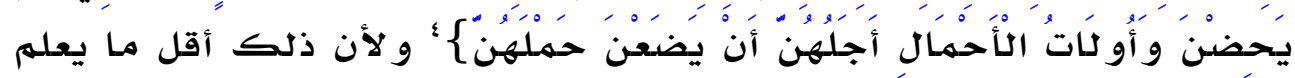

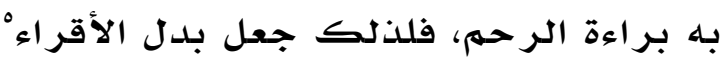
والصغيرة التي لا تطيق الرجال لا عدة عليها، قال أبو محهمد عبد الوهاب: من لهم تبلغ أن تطيق الرجال فأصيبـ، فلا يكون و طؤها مـوجبًا للعدة، و إنها هو جر ح و إفساد'

وجه حماية الذريعة في استبراء الصغيرة التي تطيق الوطء: يظهر وجهه حماية الذريعة في الخشيـة مـن الحهل لهـن يغلب على الظن حملها أو يشك فيها وقاعدة المذهب في ذلك: أن من غلب على الظن كونها حاملا، أو شك في حملها، وتردد فيـ، فالاستبـراء لازم فيها، وكل من غلب على الظن براءة رحمها، لكنه مـع الظن الغالب يجوز حصو له، فإن المدذهب على قو لين في ثبوت الاستبـر اء و سقوطه.

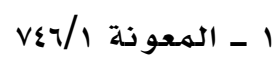

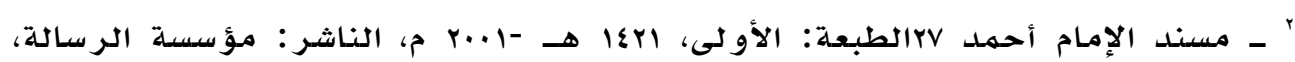

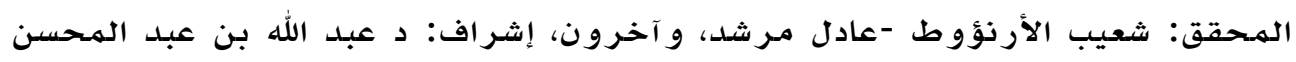

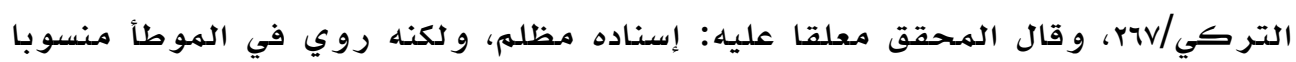

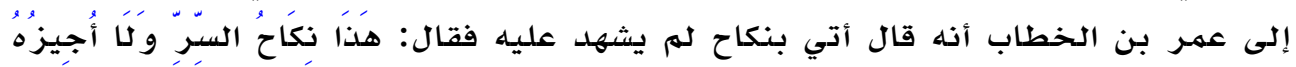

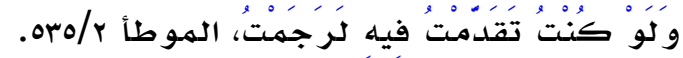

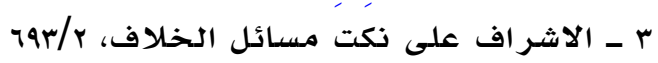

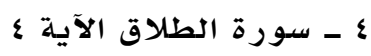

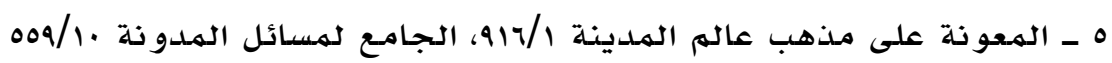

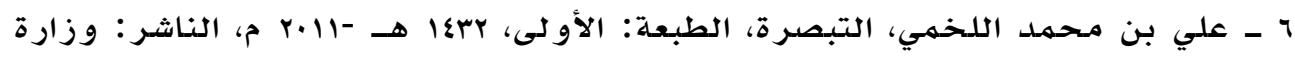
rol

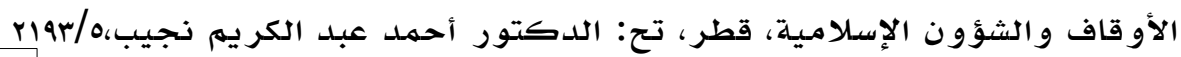


قال جلال الدين عبد الله بن نجم بن شاس عطفا على هذه القاعدة: ثم خرج على ذلك الفروع الهختلف فيها، كاستبراء الصغيرة التي تطيق الوطء، أو اليـائسة، قال: لأنه يهكن فيها على الندور، أو لحمـاية الذريعة، لكئلا يدعى في مو ضع الإمكان أن لا إمكان'.

المطلب الثالث: مسائل في المعاشرة الزوجية المسألة الأولى: الاستمتاع بالحائض بما تحت الإزار: للمهذهب فيها رأيان:

الأول: لا يجوز الاستهماع بـالحائض بها تحت الإزار وهو مـا بين السرة

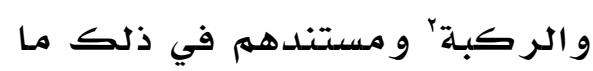

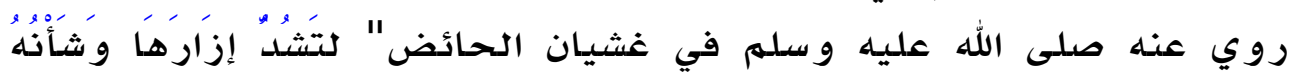

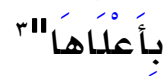

الثاني: إباحة كل شيء مـنها ما عدا الفرج على ظاهر مـا روي عن عائشـة رضي الله تعالى عنها - أنها قادت لهن سألها عن ذلك: كل شيء لك منها حلال، مـا عدا الفرج". و إلى هذا ذهب أصبـنْ وجه حماية الذريعة في المنع من مباشرة الحائض فيما دون الإزار: قال اصببغ: إنهما أمرت أن تشد عليها إزارها لئلا يصيبـه شيء هـ دمها في مضاجعته إياها، وجعل النهي الوارد عن مباشـرتها فيها دون الإزار مـن باب

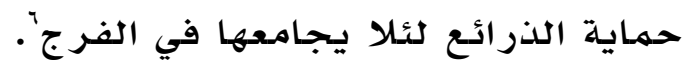

1 ـ عقد الجواهر الثمينة في مدهب عاله المدينة،MNM

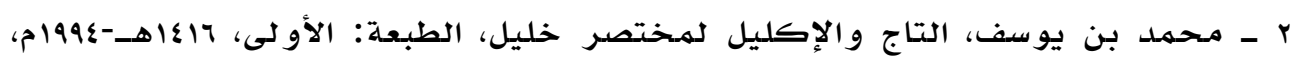

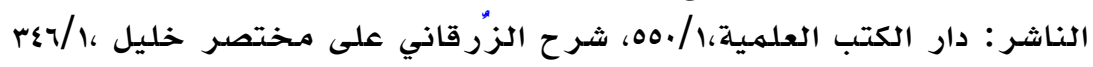

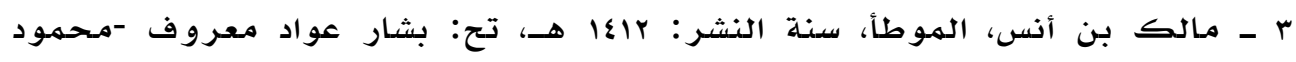
خليل، إ/

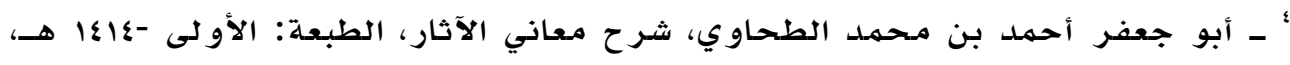

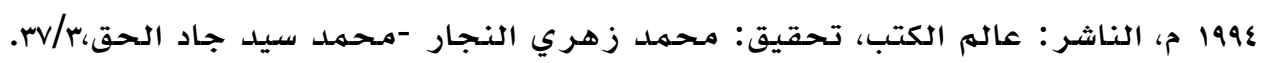

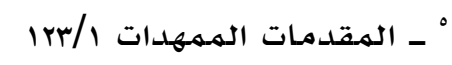

7 ـ الهقدمات الهمههدات //لهما. 
المسايلة الثانية: عدم جواز استمتاع الزجل بامرآته إن تزوجت بآخر بسبب

نعيه tها:

الهشهور في المذهب أن الهر أة إذا تزوجت بآخر بسبب نعي زوجها لها أنها ترد لزوجها الأول و إن و لدت أو لادا؛' لأنها كذبت و عجلت و نكحت من غير اعتداد و لا تربص مـن سلطان و تعتدُ في بيتها التي كانت تسكُن فيـا

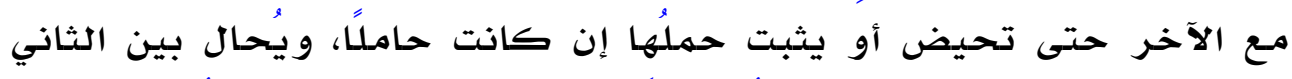

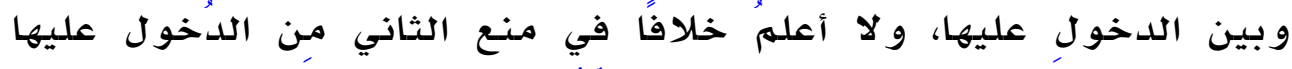

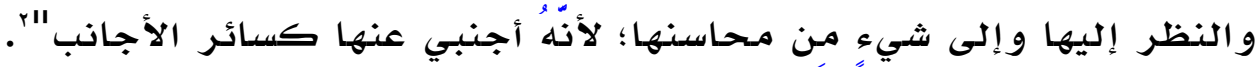
وقيل: تفوت بـخول الثاني وقيل: إذا حكمه بـه حاكم، أمـا إذا لهم يدخل

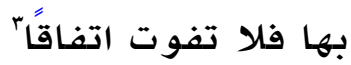

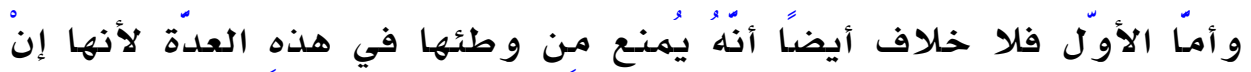

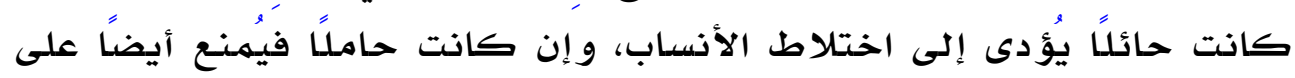

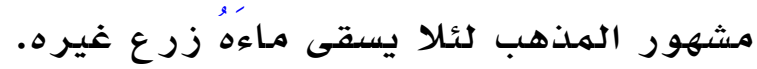
و قد ذهب بعض الهتأخر ين إلى إباحة ما عدا الوطء مـن أنواع الاستهتاع؛ لأنها زوجتهُ و إذها حبُست عنـهُ لأجل اختلاط النتسبين كها لو ابتدأها مَن زنا أو غصـ

وجه حماية الذرائع في منع الزوج الأول من سائر أنواع الاستمتاع: المـذهب منـع الزوج الأول مـن سـائر أنواع الاستهـتاع ودواعي الوطء مخافة أن يقوده ذلك إلى الوطء المؤدي إلى اختلاط الأنساب ن وقد رد

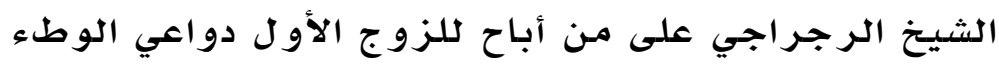
بقوله :" و مـا قاله غير صحيح و مذهبنـا حماية الذرائع .

أـ شرح مختصر خليل ،\&/101، والذي حكم بعدم الخلاف هو أبو الحسن الرجراجي،

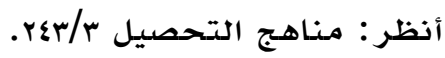

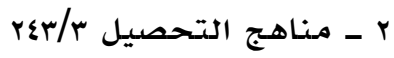

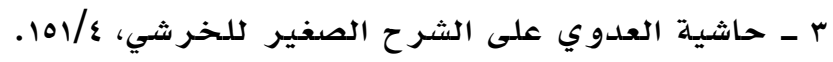

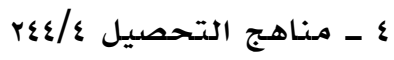

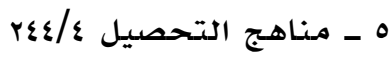


المسالة الثالثة: ما يباح للزوج من زوجته قبل أن يسترجعها إذا كان

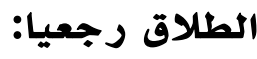

لا خلاف أنه لا يجوز له مباشر تها إذا لهم يقصد بذلك رجعتها، و لا النظر

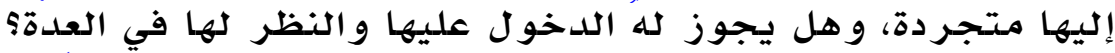

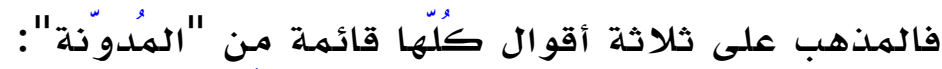

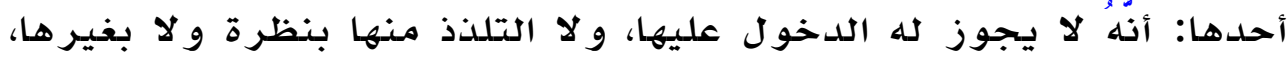

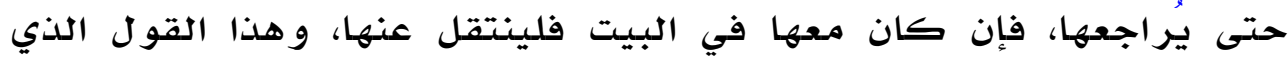

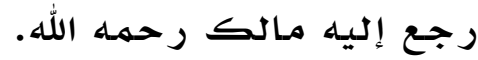

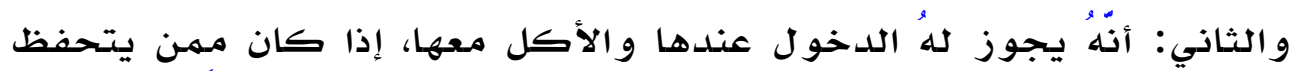

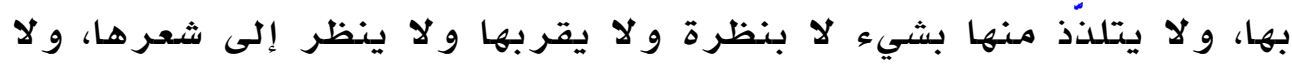

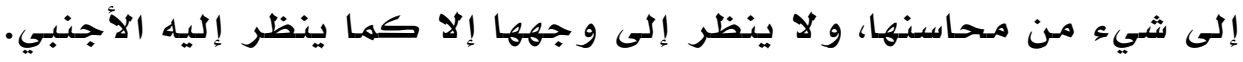

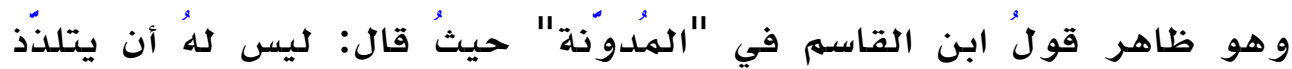

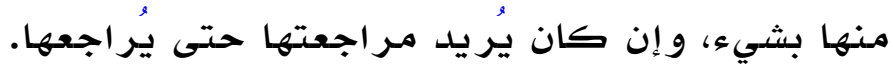

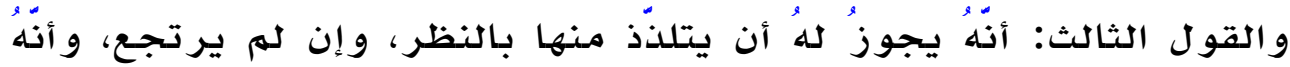

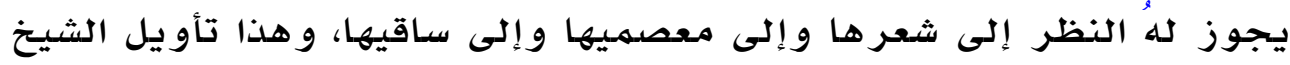

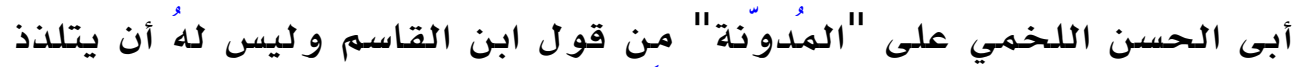

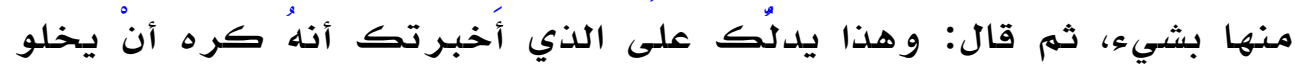

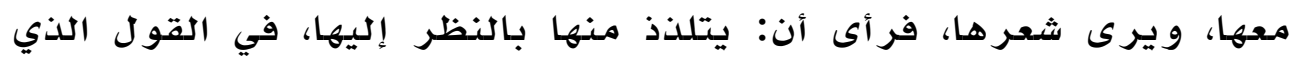

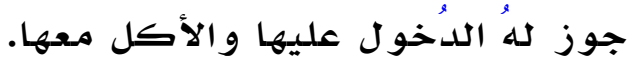

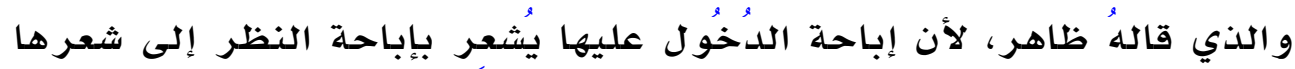

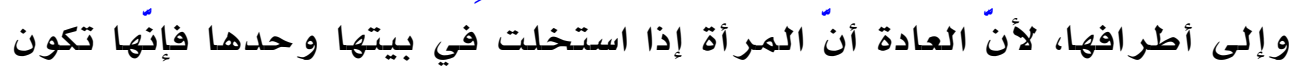

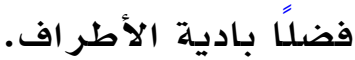

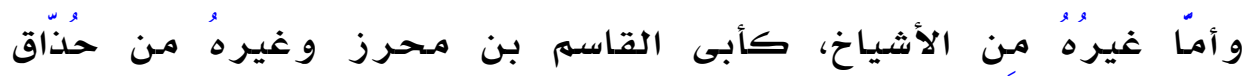

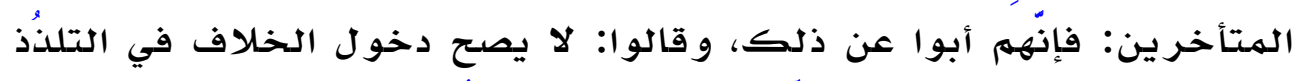

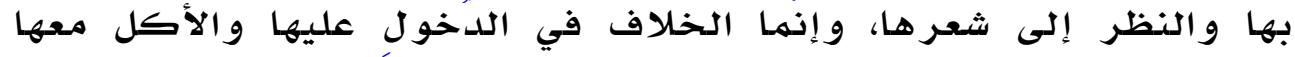

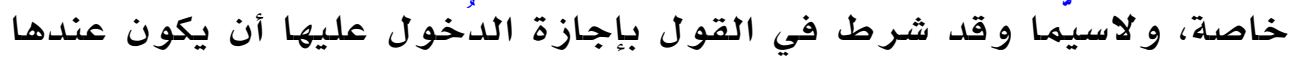

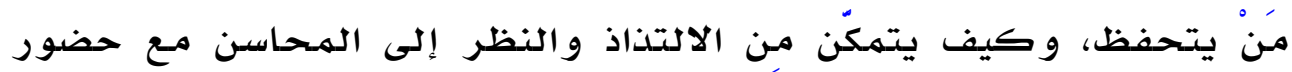


و هذا الذي قالوهُ أيضًا ظاهر المدلدونة إلا أن الذي عليه الفتتيا: لا يجوز

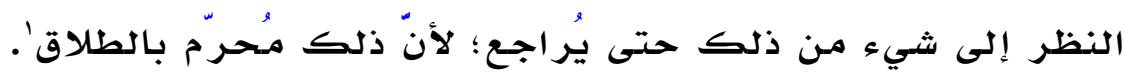
وجه حماية الذريعة في علم جواز دخول المطلق على مطلقته والتلذذ بالنظر إليها و غيره:

قال أبو الحسن الرجراجي بعد ذهره ذهذه الأقوال:" وسبب"

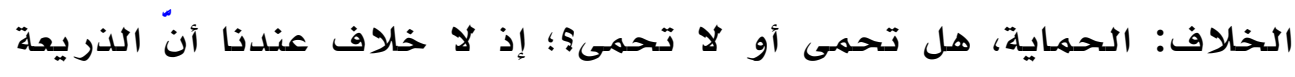
تُحهى، و اختّلف في حهايتها هل تُحهى أو لا تُحهى؟ فهن رأى أنها تحهى،

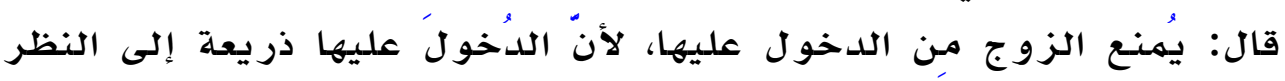

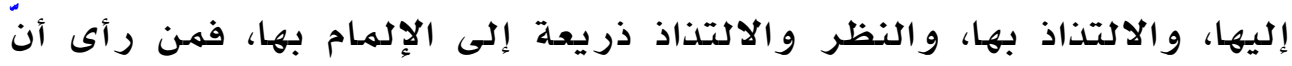
الحماية لا تُحمى قال: بجواز الدخول عليها'، والذي يترجح عندي الهنع من الدخول عليها حماية لذربعة الإلهام بها، و الله أعلهم.

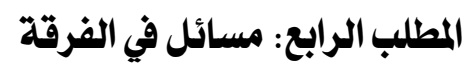

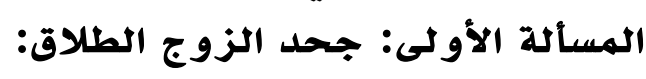
إن اعترف الزوج بالطلاق فلا إشكال بأنه يحكم عليه بهقتضى ما اعترف بـه مـن الطلاق، و إن جحد الطلاق فلا يخلو من أن أن تشهد عليه البينة بالطلاق أو لا تشهد عليه، فإن له تشهد عليه البينة، فلا يهين عليه باتفاق الهـذهبr

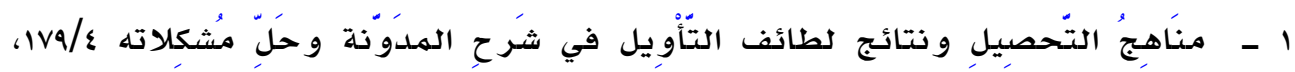

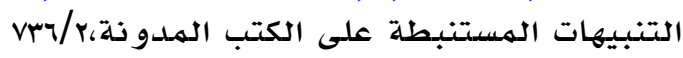
r - الهـرجعين السـابقين.

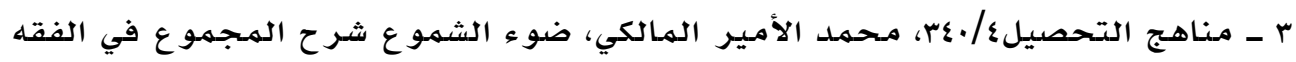

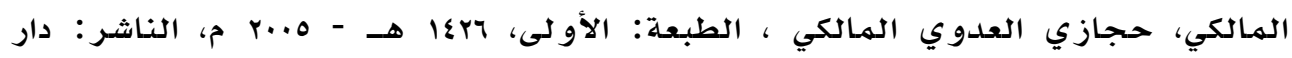

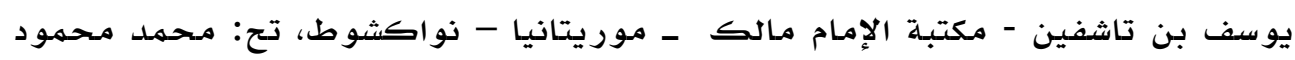

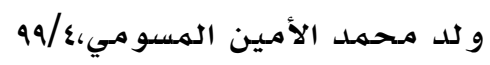


وجه حماية الذريعة في عدم إلزام الزوج باليمين في حال عدم وجود بينة على الطلاق:

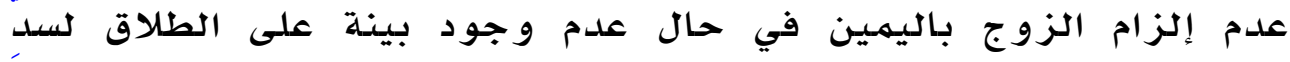

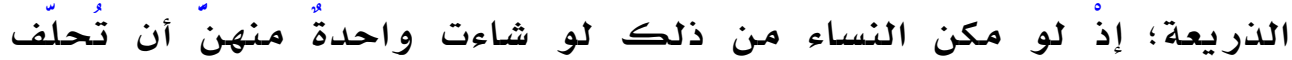

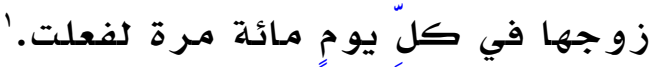

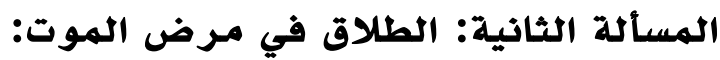

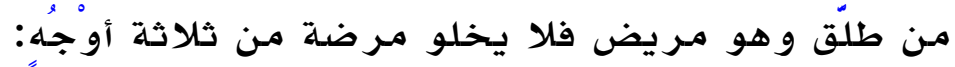

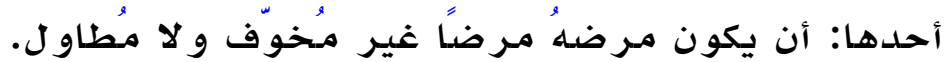

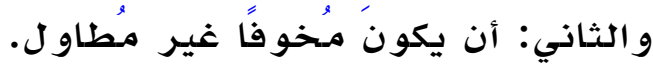

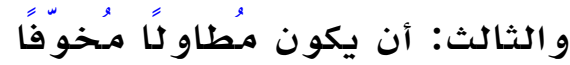

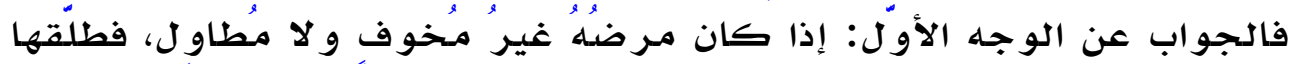

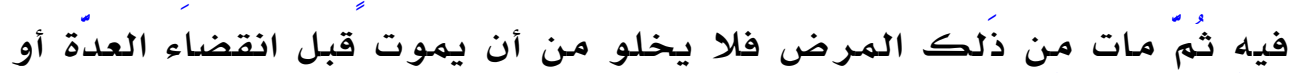
مـات بعد انقضائها.

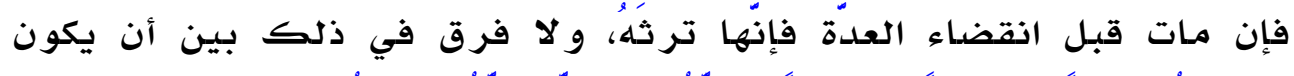

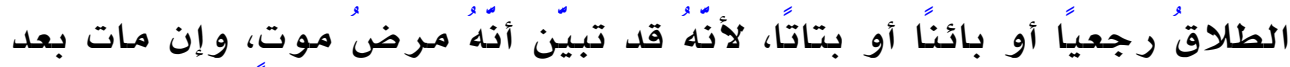

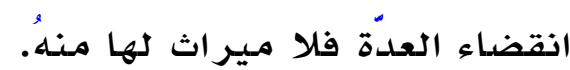

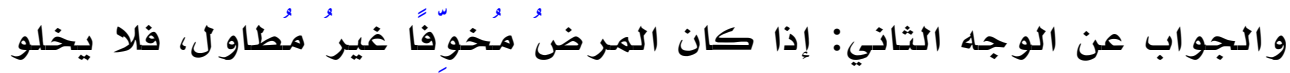

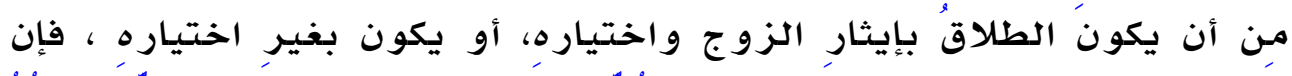

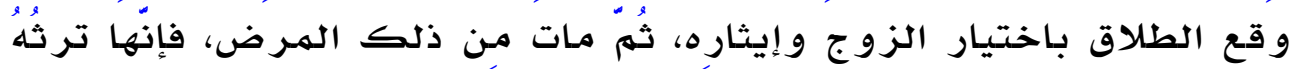

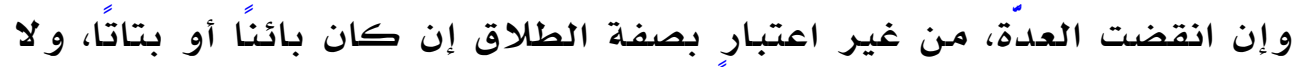

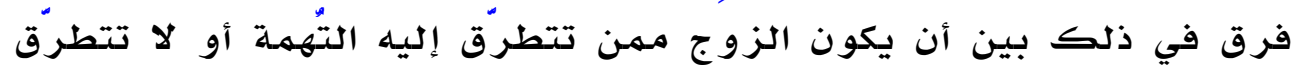

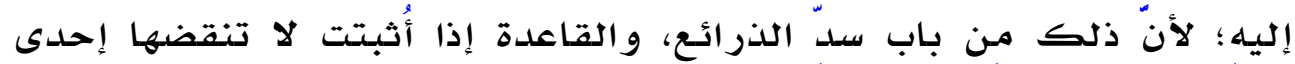

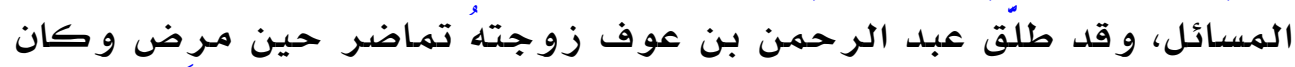

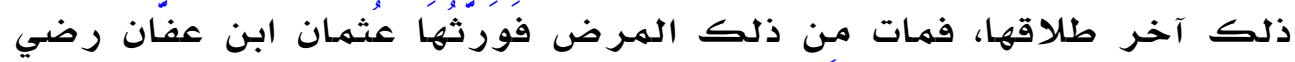

1 ـ مناهج التحصيلـ/.عr، ضوء الشموع شرح المجموع في الفقه المالكي،/99 
الله عنهله مـن تركة عبد الرحمـن. فقيل لله: أتتهم أبا محهمئ فقال: "لا و لكنها السنَّة يهاب النـاس الفرار مـن كتاب الله تعالى "'.

وجه حماية الذريعة في عدم عد الطلاق في مرض الموت مانعا للمرأة من المير اث: أمير:

قال الرجراجي: فإن قيل: لهم اتهم الهـريض بطلاق المر أته في مير اثها، و لهم يتهم في صداقها، إذا كان الطلاقُ قبل البناء حيثُ له يجعل لها إلا نصف الصداق، و ما الفرق بين الهيراث و الصداق عندكه، والتهمهة إذا

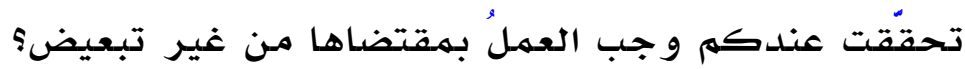

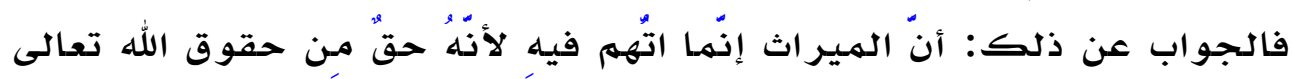

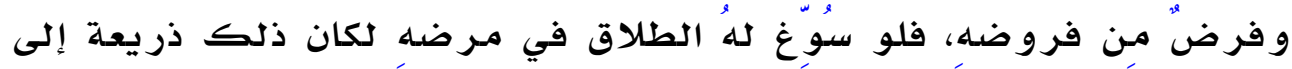

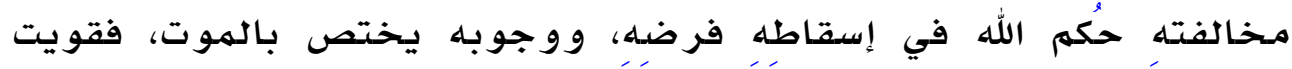

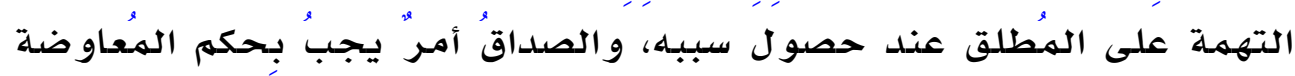

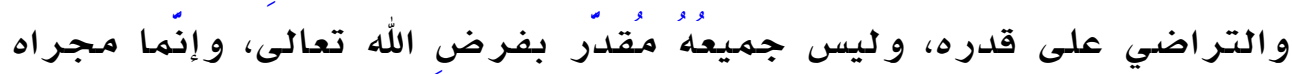
فيهما يزيد على ربع دينار مـجرى حقوق الآدميين من الديون و غيرها، و لهم

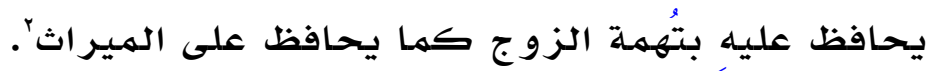
المسالة الثاثثة: مباشرة المظاهر لامرأه فيما دون الوطه. فيمها يجوز للهُظاهر مـن امر أته قبـل الكفَّرة أربعة أقوال: أحدها: إباحة مـا عدا الوطء مـع الكر اهلة.

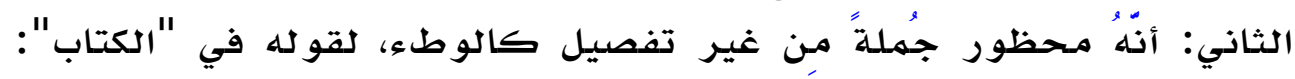

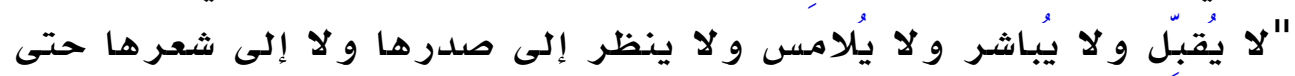
"يُكفِ الثالث: التفصيل بين القبّلة و الهُبـاشـرة و النظر إلى الهحاسن.

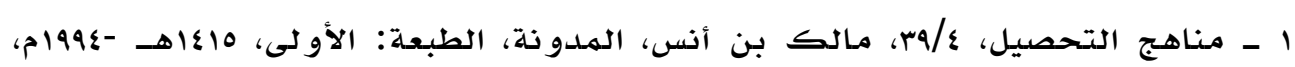

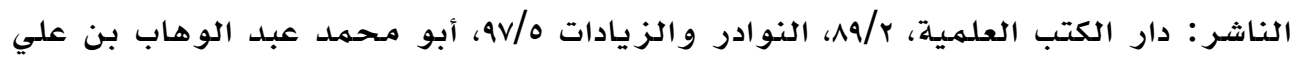

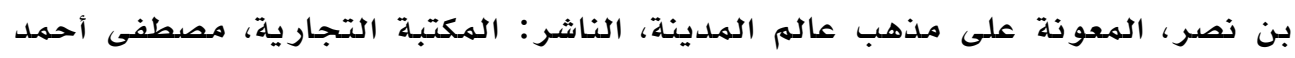

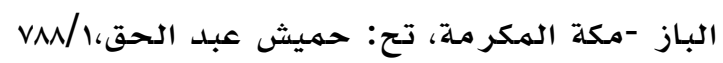

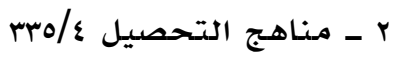




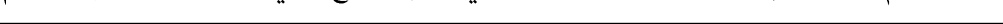

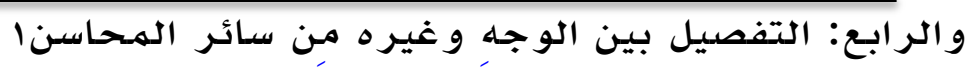

وسبب الخلاف: اختافهم في دواعي الوطء، هل هي كالوطء أم أم لاء

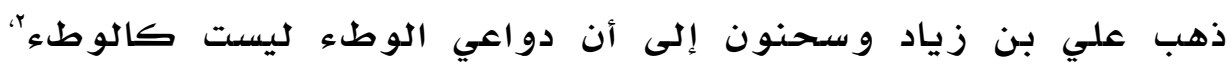

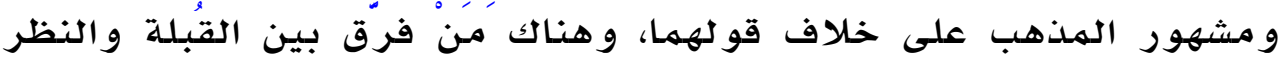

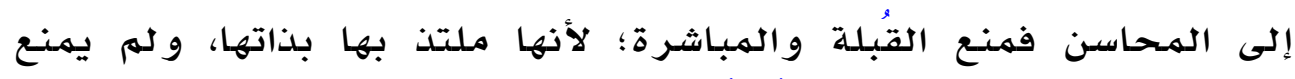

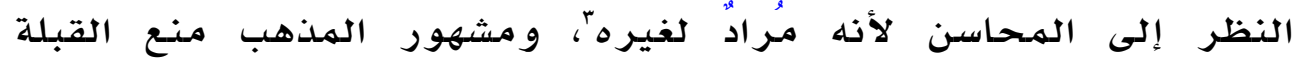

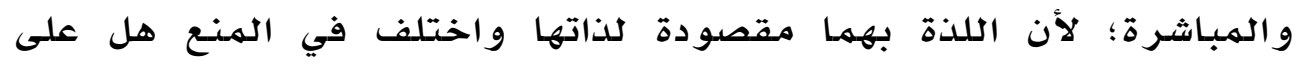

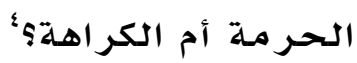

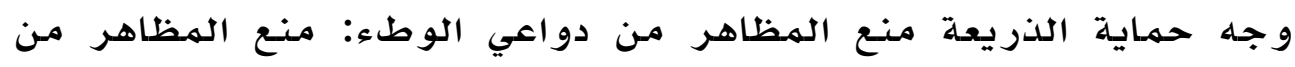

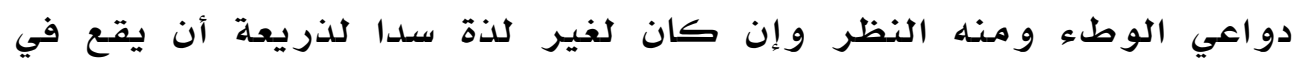

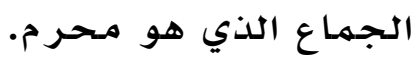

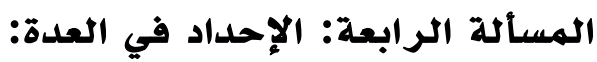

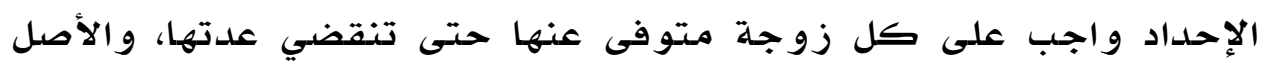

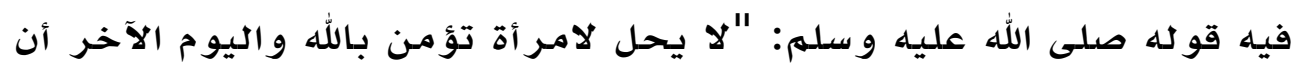

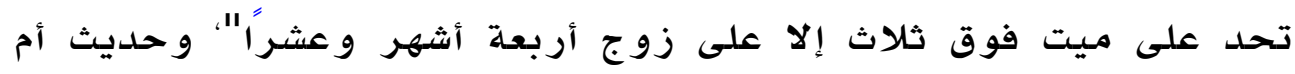

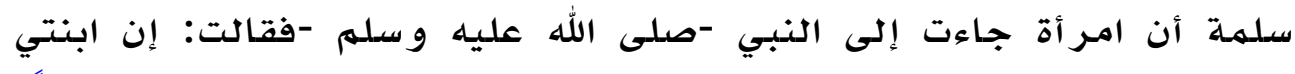

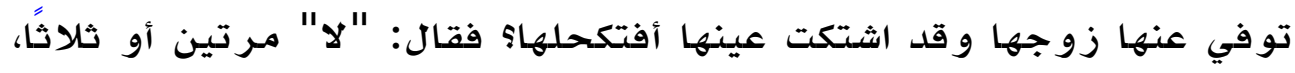

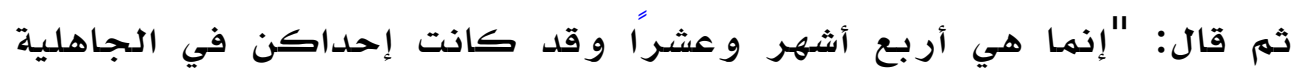

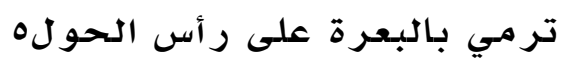

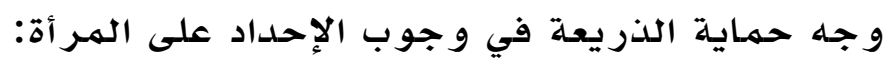

$$
\begin{aligned}
& \text { Vع/o، مناهج التحصيل }
\end{aligned}
$$

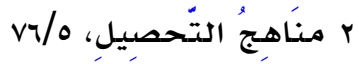

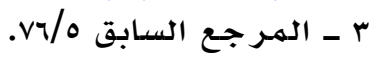

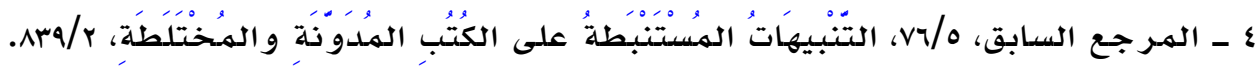

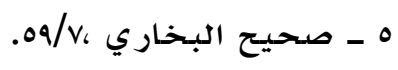


و جب على الهر أة الإحداد حتى لا تتشوف إليها الرجال' في العدة و لا تتشوف هي إليهم؛ وذذك سدا للذريعة لهكان حفظ الأنسـاب'

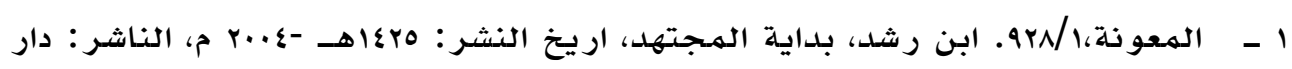

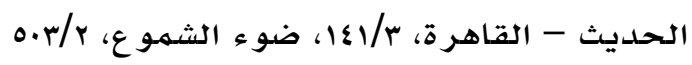


الخاتمة:

الحمد الله الذي يسر بمنـه وكرمـه طريق الخير للعباد، وأرسل إليهم

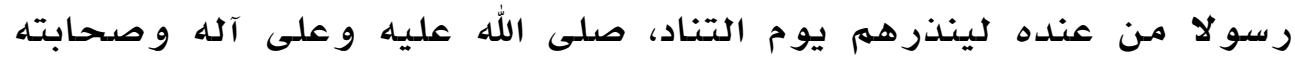

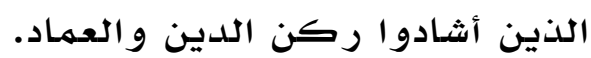

\section{و بعد...11}

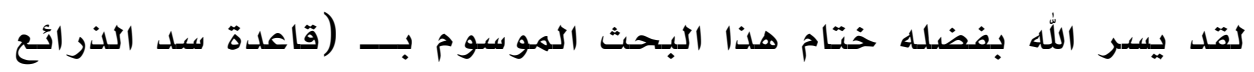

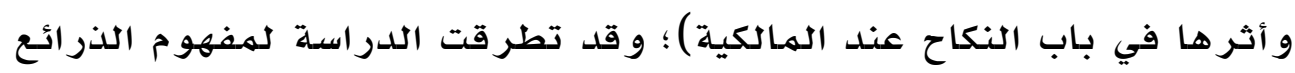

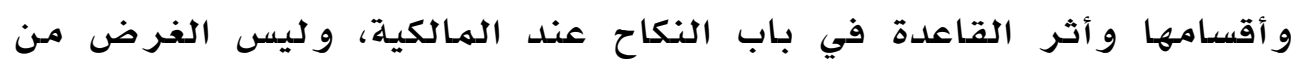

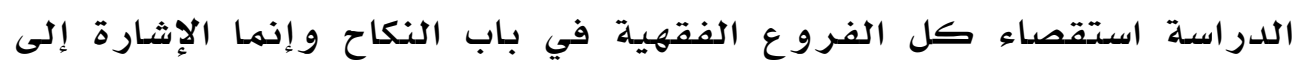

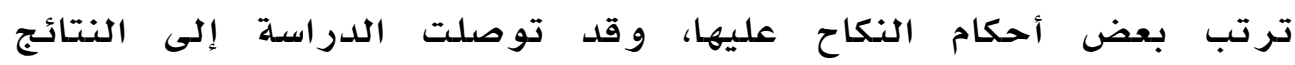

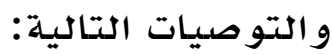

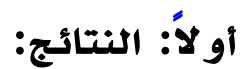

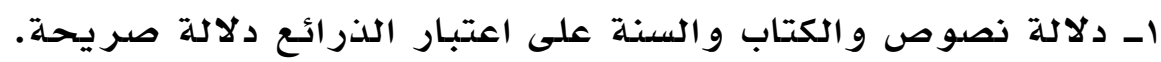

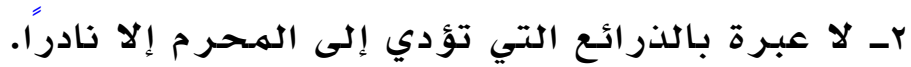

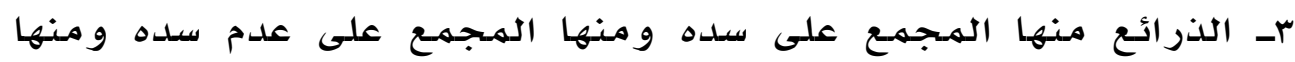
الهختلف فيهـ.

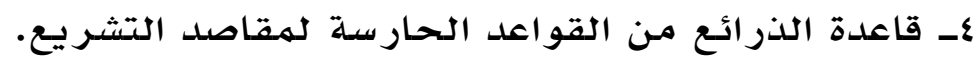

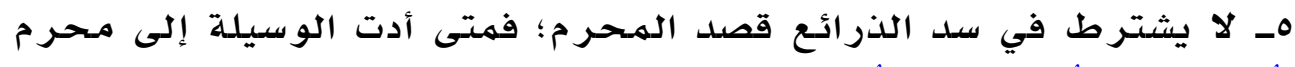

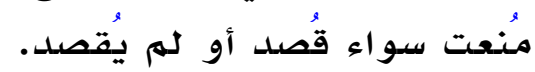

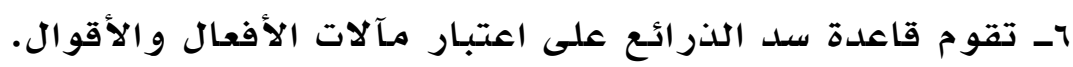

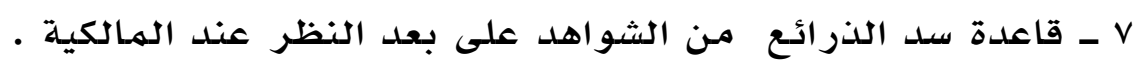

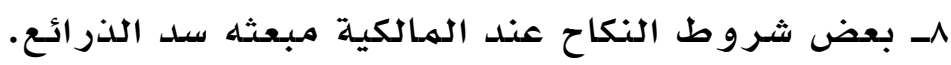

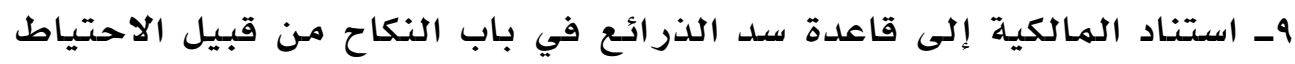

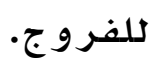
•ا- راعى المالكية بإعمالهم لقاعدة سد الذرائع في باب النكاح مقصد النسل. 1ا- من ضوابط النظر في سد الذرائع عند المـالكية قرائن الأحوال التي تثبت التهمة أو تنفيها. 


\section{ثانيا: التوصيات:}

اـ توصي الدراسـة طلاب العلهم والباحثين بسبر أغوار الأثر الفقهي لقاعدة

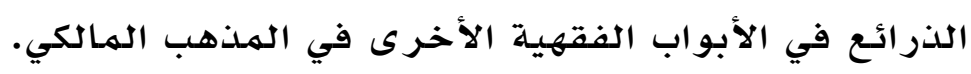

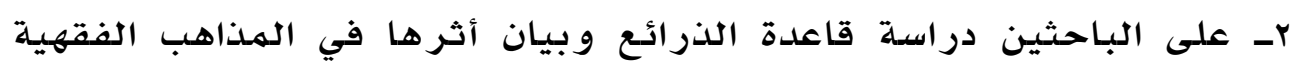
الأخرى.

rـ على الباحثين والعلماء تدقيق النظر في مآلات الأفعال و عدم التسرع في

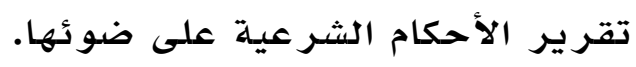
و آخر دعوانا أن الحمد الله رب العالمين. 


\section{فهرس المراجع:}

أولا: القر آن الكريم و علومهه:

ا- القر آن الكريهم رواية حفص.

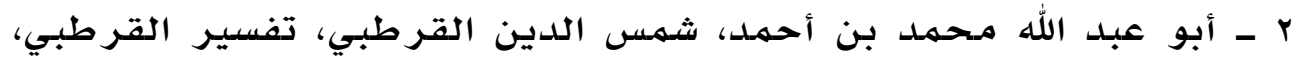

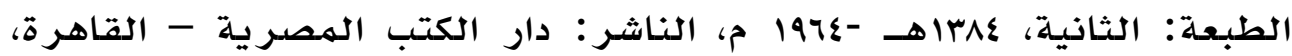
تح: أحمد البر دو ني و إبر اهيم أنفيه أطفيش.

r - محمد بن جرير الطبري، جامع البيان في تأويل القر آن، الطبعة:

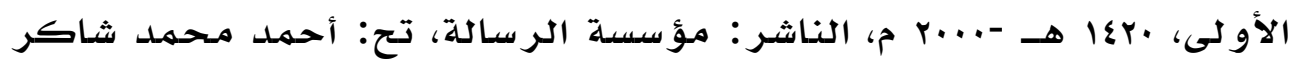

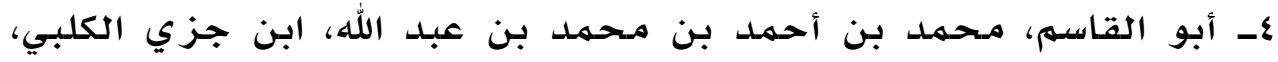

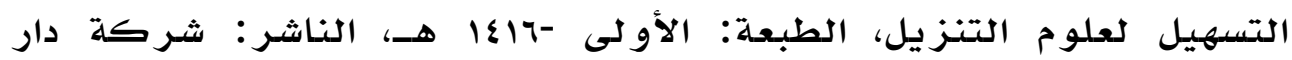

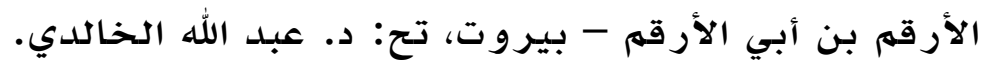

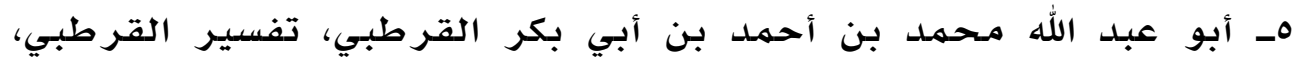

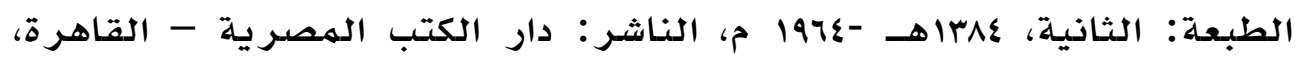

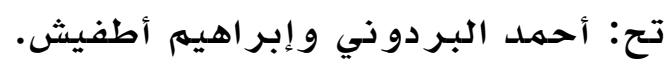

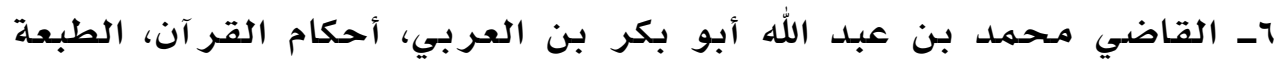

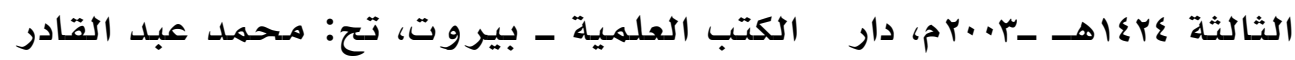
عطا.

\section{ثانيا: السنة:}

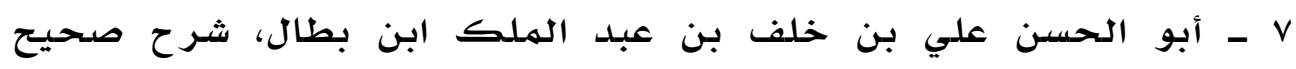

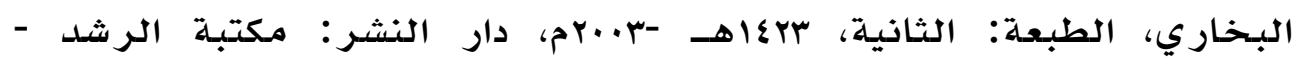
السعوديـة، الرياض، تح: أبو تميهم يـاسر بن بن إبر اهيهم 
ـ ـ أبو داود سليمان بن الأشعث، سنن أبي داؤود، الطبعة: الأولى، .بعا هـ -

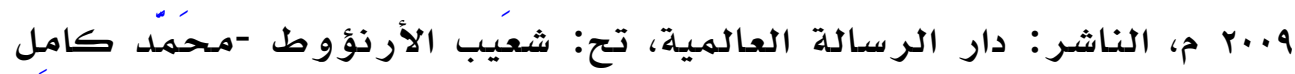
قره هـلمي.

9 - أبو عبد الرحهن أحمد بن شعيب النسيائي، السنن الكبرى، الطبعة:

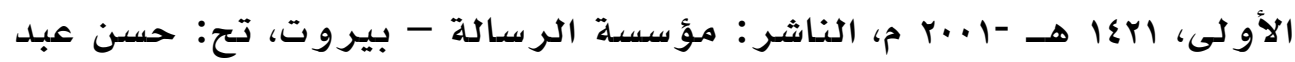
الهنعم شلبـي.

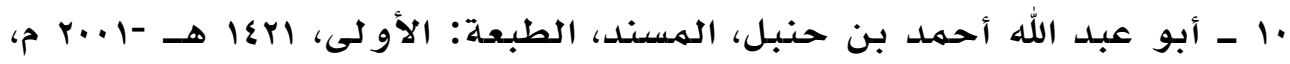
الناشـر: مؤسسة الرسالة، تح: شعيب الأرذؤوط -عادل مـرشـ، و آخرون. 1 ـ الإمام مـحمد بن اسهـاعيل البخاري، الجـامـ الصحيح ، الطبعة: الأولى،

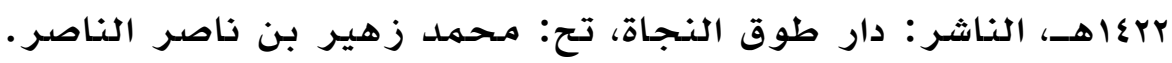
r ـ مـالك بن أنس، المهوطأ، سنـة النشر: rإعا هـ، تح: بشار عواد معروف -محمهود خليل.

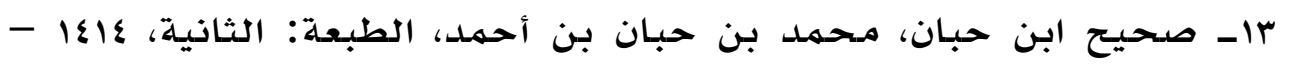
سو99، الناشـر: مؤسسة الرسالة - بيروت، تح: شعيب الأرنؤوط

\section{ثالثا: كتب اللغة:}

عا- ابن منظور، محمد بن مكرم، لسـان العرب، الطبعة: الثالثة -عاع| هـ، الناشر: دار صادر - بيروت.

10ـ أبو هلال الحسن بن عبد الله العسكري، الفروق اللغوية، الناشر : دار العلهم والثقافة للنشر والتوزيع، القاهرة - مصر- تح: محمد ابر اهيهم سليهم 17- زين الدين أبو عبد الله محمد بن أبي بكر، مختار الصححاح، الطبعة:

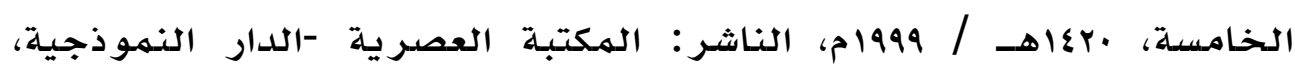
بيروت - صيدا، تح: يوسف الشيخ محمد. 
او زين الدين محمهد المدلدو بعبد الرؤوف، التوقيف على مهمهات التعاريف، الطبعة: الأو لى، ·اعاهـ-·199ام، الناشر : عاله الكتب ـ القاهرة

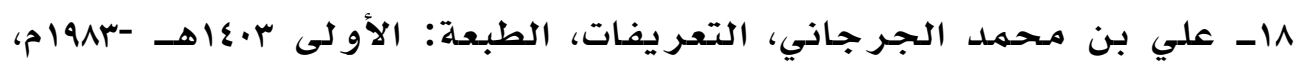
الناشر : دار الكتب العلمية بيرو ت -ذبنان

19- محمهد بن القاسهم بن محمد بن بشار، أبو بكر الأنباري، الزاهر في معاني كلهـات الناس، الطبعة: الأولى، باعا هـ -199r، الناشر: مؤسسة الرسالة - بيروت، تح: د. حاتم صاتح الضامن.

•r- محمدد بن القاسهم بن محهد بن بشار، أبو بكر الأنباري، الزاهر في معاني كلهـات الناس، الطبعة: الأو لى، باعا هـ -199r، الناشـر: مؤسسـة الرساتة - بيروت، تح: د. حاتم صاتح الضامن.

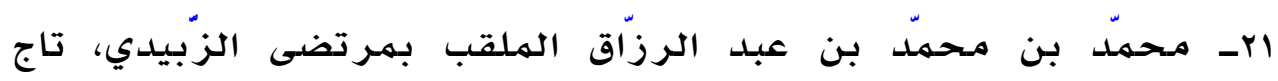
العروس مـن جواهر القاموس، الناشر : دار الهداية، مـجمو عة من الهحققين.

رابعا: أصول الفقه:

rr - إبر اهيهم بن موسى بن مححمد اللخمي الشاطبي، الهوافقات، الطبعة:

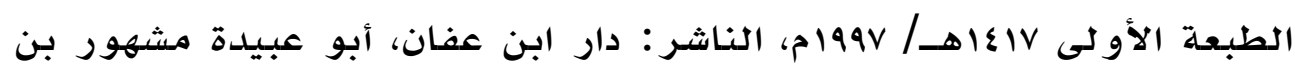
حسن آل سلهمان.

بr - أبو العباس شهاب الدين أحمد بن إدريس بن عبد الرحمـن الهـالكي الشهير بالقرافي، شرح تنقيح الفصول، الطبعة: الأولى، سوسا هـ -19Vr م، شر كة الطباعة الفنية الهتحدة، تح: طه عبد الرؤوف سعد.

ع - ـ أبو العباس شهاب الدين أحمد بن إدريس بن عبد الرحمن المالكي الشهير بالقر افي، الفروق، الناشر : عالهم الكتب. 
O - أبو عبد الله محمد بن أبي بكر بن أيوب ابن قيم الجوزية، أعلام الهموقعين عن رب العالهين، الطبعة: الأولى، سrعا هـ، الناشر: دار ابن الجوزي للنشر و التوزيع، الهملكة العربية السعودية، تح: مشهور حسن.

جr - أحمد بن محمدل مكي، غمز عيون البصائر الطبعة: الأولى، 0.عاهـ 1910 م، الناشر : دار الكتب العلهيـة.

rV _ الدكتور/ صدالح بن سعود آل علي، الذرائع والحيل وموقف الشريعة منهمها، مكتبـة العبيكان.

^ ـ تاج الدين عبد الوهاب بن تقي الدين السبكي، الأشبـاه والنظائر، الطبعة: الأو لى العاهـ-1991م، الناشر : دار الكتب العلهي

هץ - سليهان بن عبد القوي بن الكريم الطوفي الصر صري، شرح مختصر

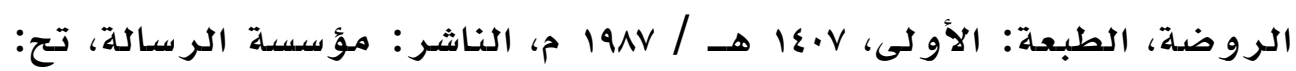
عبد الله بن عبد الهـحسن التر كي.

• • ـ محمدد بن أحمد سيد أحمد زروق، سـد الذرائع في الهذهب الهـالكي، دار ابن حزم

اب ـ محهمد هاشمم البرهاني، سـد الذرائع في الشر يعة الإسـلاميلة، الطبعة

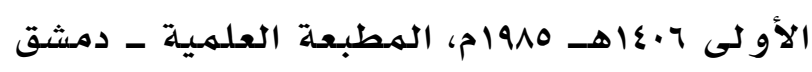

خامسا: الفقه:

بr- أبو الحسن علي بن أحمد العدوي، حاشية العدوي على شرح كفاية الطالب الرباني، اريخ النشر : عاءاهـ -\&99ام، الناشر : دار الفكر - بيروت، تح: يو سف الشيخخ محهد البقاعي.

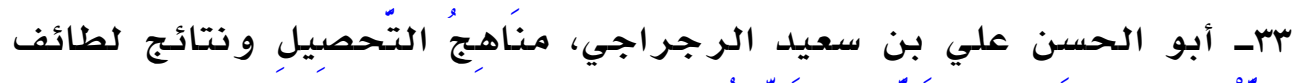

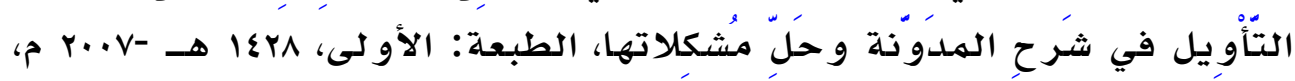

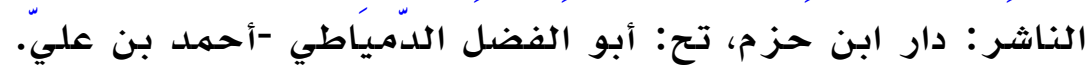


عَـ أبو العباس شهاب الدين أحهد بن إدريس بن عبد الرحهن الهالكي الشهير بالقرافي، الذخيرة، الطبعة: الأولى، 1998 م، الناشر: دار الغرب الإسـلا مي -بيروت.

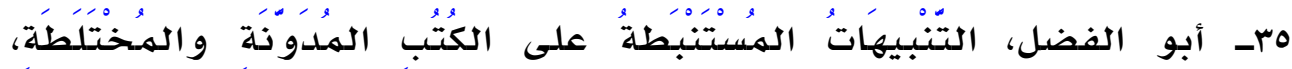

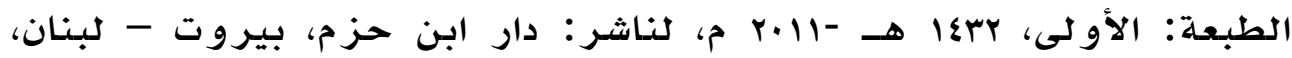
تح: د. محهمد الوثيق، د.عبد النعيهم حمـيتي.

جسـ أبو الوليد محمد بن أحمد بن رشد القرطبي، البيان و التحصيل و الشرح و التوجيه و التعليل لمسـائل المستخر جـة، الطبعة: الثانية، 1•عا هـ -1911 م، النـاشـر: دار الغرب الإسـلامي، بيروت - لبنان، تح: د محمهد حجي و آخر

VY- أبو الوليد محمد بن أحمد بن رشد القرطبي، الهقدمات الهمهدات، الطبعة: الأولى، ^•عا هـ -1911 م، الناشر: دار الغرب الإسلامي، بيروت لبنان، تح: د. الدكتور محهد حجي.

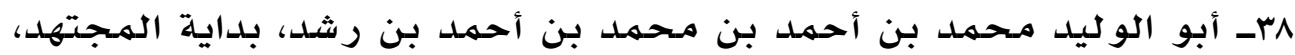

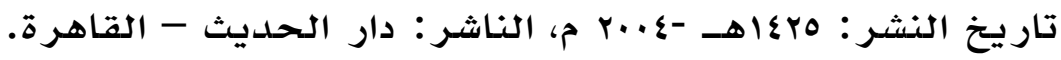

هبـ أبو بكر محمد بن عبد الله بن يونس التميهي الصقلي، الجـامـع لهسائل المدونة، الطبعة: الأولى، عبعا هـ -سا•r م، دار الفكر للطباعة و النشر و التوزيع، الناشر: معهد البحوث العلمية و إحياء التراث الإسلامي -جامعة أم القرى، تح: مجهموعة من الباحثين.

•عـ أبو عبد الله محمدل بن أبي بكر بن أيوب ابن قيهم الجوزيهة، إغاثة اللهفان في حكهم طلاق الغضبان، مكتبـة الهعارف، الرياض، الهملكة العربية السعودية، تح: مححمد حامد الفقي. 
اعـ أبو عمر يوسف بن عبد البر، الكافي في فقه أهل الهدينة، الطبعة:

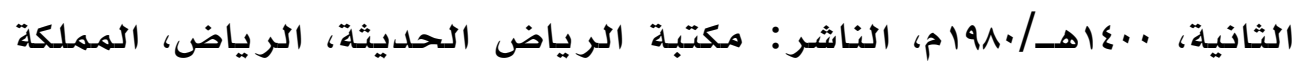
العربية السعودية، تح: محمهد محمدل أحيد و لد مـاديك الموريتاني.

بعــ أبو محهمد عبد الله بن أبي زيد القيرواني، النّوادر والزّيـادات على مـاً

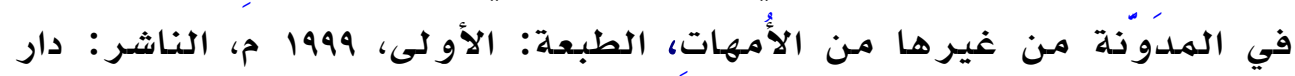
الغرب الإسـلامي، بيروت، تح: د. عبد الفتّاح محمدد الحلو و آخرون، محمد بن أحمد بن عرفة الدسوقي المالكي، حاشيـة الدسوقي على الشرح الكبير، الناشر : دار الفكر •

بعـ أبو محمدد عبد الوهاب بن علي بن نصر، الهعونة على مـذهب عالم الهمدينة، النـاشر : الهكتبـة التجارية، مصطفى أحمد البـاز -مكة الهكر مـة، تح: حميش عبد الحقّ.

عــ أحمد بن محمدل الصاوي المالكي، بلغلة السـالك لأقرب المسالك إلى مذهب الإمـام مـالك، عام النشر : IrVY هـ -190r م، الناشر: مكتبـة مصطفى البابي الحلبي.

هـ- تقي الدين أبو العباس أحمد بن عبد الحليه بن تيهية، مجهموع

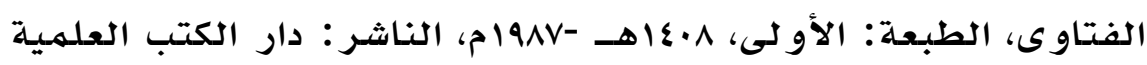

جعـ جلال الدين عبد الله بن نجم بن شاس، عقد الجواهر الثهينة في مذهب

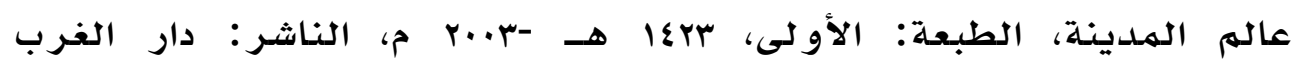
الإسلالمي، بيروت - لبنان، تح: أ. د. حميد بن محمد لحمـر .

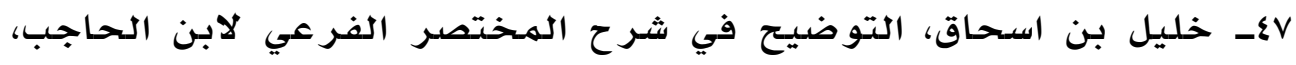

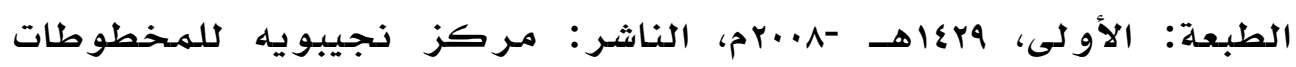
وخدمـة التراث، تح: د. أحمد بن عبد الكريهم نجيب.

عــ شهس الدين أبو عبد الله مححمد بن محهمد الحطاب، مواهب الجليل في شرح مـختصر خليل، الطبعة: الثالثة، rاعاهـ -r99ام، دار الفكر • 
ه§- عبد الباقي بن يوسف بن أحمد الزرقاني، شرح الزرّرقاني على مختصر

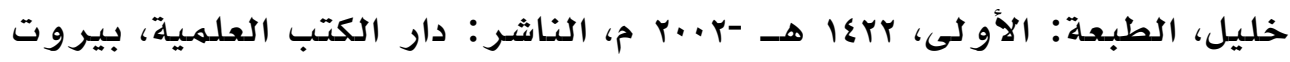
- لبنـان، تح: عبد السـلام مـحمد أمين.

•ــ عبد الباقي بن يوسف بن أحمد الزرقاني، شرح الزرّقاني على مختصر

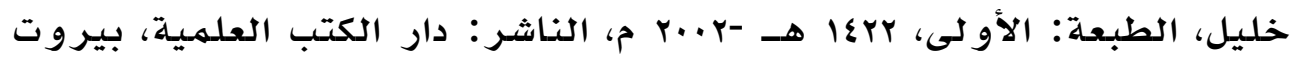
- لبنان، تح: عبد السـلام محمد أمين.

ا0ـ علي بن أحهد العدوي، حاشية العدوي على الشرح الصغير للخرشي، مطبوع بهامش شرح الخرشي على مختصر خليل، دار الفكر للطباعة -

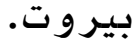

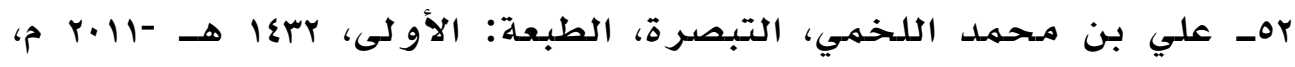
الناشر: وزارة الأوقاف والشؤون الإسـلاميلة، قطر، تح: الدكتور أحمد عبد الكر يهم نجيب.

بهـ قاسهم بن خلف بن فتح بن عبد الله بن جبير، أبو عبيد الجبيري، التوسط بين مـالك وابن القاسهم في المسائل التي اختلفا فيها من مسائل

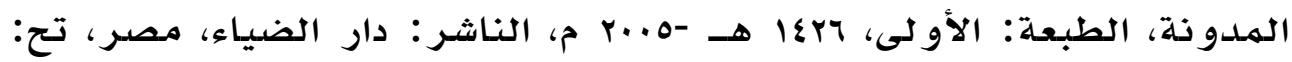

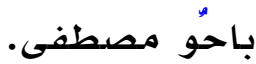

\&هـ قاسـم بن عيسى التنوخي، شرح ابن ناجي التنوخي على متن الرسالة،

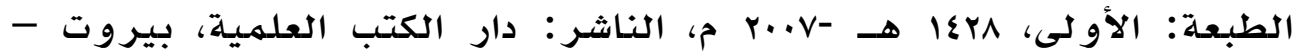
لبنان، تح: أحهد فريد الهزيدي.

هــ القاضي أبو محمد عبد الوهاب بن علي بن نصر البغدادي الهـالكي، الإثـراف على نكت مسـائل الخلاف، الطبعة: الأولى، ·r\&اهـ -1999 م، النـاشـر: دار ابن حزم، تح: الحبيب بن طاهر • هـ_ مـالك بن أنس، الملدونة، الطبعة: الأولى، إعاهـ -\&99ام، الناشر : دار الكتب العلميـة. 
_oV محمد الأمير الهمالكي، ضوء الشهوع شرح الهـهموع في الفقه الهـالكي،

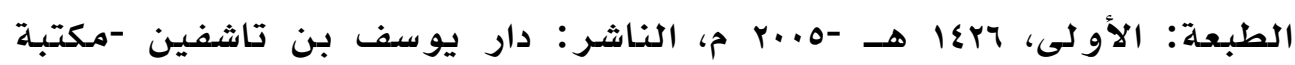
الإمـام مـالك - موريتانيا - نواكشوط _، تح: محمهد محمود و لد محمد

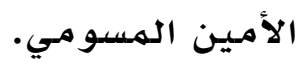

هـ مـحمد بن أحمد بن محمهد عليش، منتح الجليل شرح مـختصر خليل،

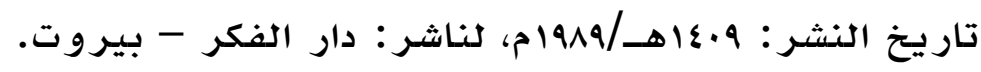

9هـ مـحمد بن عبد الله الخرشي، شـرح مـختصر خليل كلخرشي، الناشـر : دار الفكر كلطباعة - بيروت.

•ج- مححمد بن محمدد بن عرفة، الهـختصر الفقهي، الطبعة الأولى،هوعاهـ، عا+rrم، مؤسسة خلف أحمد الخبتور كلأعمال الخيرية، تح: د. حافظ عبد الر حمن محهمد خير .

آ- محمدل بن محمد سـالم المهجلسي الشنقيطي، لوامـع الدرر في هتك

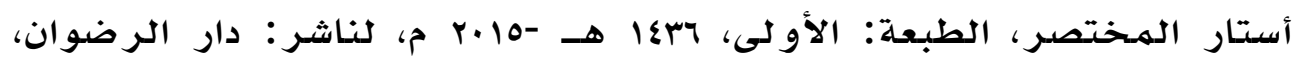
نو اكشو ط-مور يتانيا.

بآ- محمده بن يوسف، التاج والإكليل لهختصر خليل، الطبعة: الأولى،

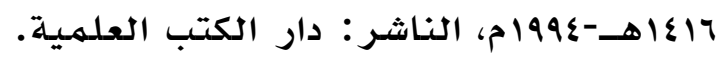

